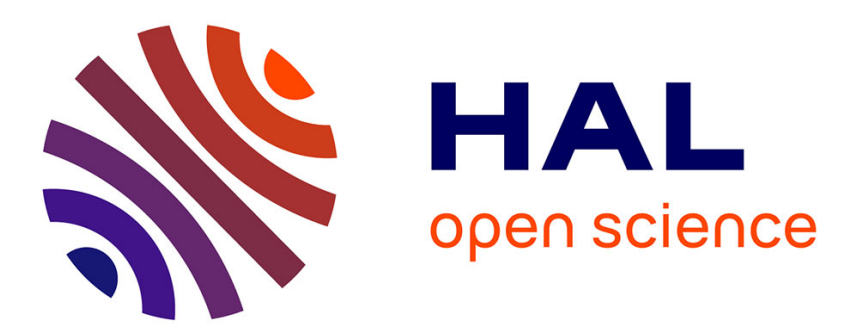

\title{
Structure-Function Relationships With Spectral-Domain Optical Coherence Tomography Retinal Nerve Fiber Layer and Optic Nerve Head Measurements
}

Frédéric Pollet-Villard

\section{- To cite this version:}

Frédéric Pollet-Villard. Structure-Function Relationships With Spectral-Domain Optical Coherence Tomography Retinal Nerve Fiber Layer and Optic Nerve Head Measurements. Human health and pathology. 2015. dumas-01254656

\section{HAL Id: dumas-01254656 https://dumas.ccsd.cnrs.fr/dumas-01254656}

Submitted on 12 Jan 2016

HAL is a multi-disciplinary open access archive for the deposit and dissemination of scientific research documents, whether they are published or not. The documents may come from teaching and research institutions in France or abroad, or from public or private research centers.
L'archive ouverte pluridisciplinaire HAL, est destinée au dépôt et à la diffusion de documents scientifiques de niveau recherche, publiés ou non, émanant des établissements d'enseignement et de recherche français ou étrangers, des laboratoires publics ou privés. 


\section{Joseph Fourier 7 F MEDECINE}

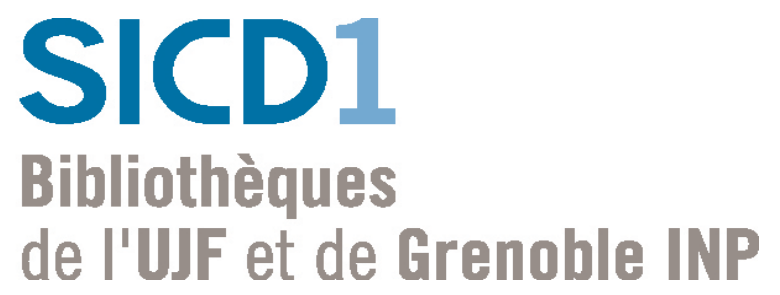

\section{AVERTISSEMENT}

Ce document est le fruit d'un long travail approuvé par le jury de soutenance et mis à disposition de l'ensemble de la communauté universitaire élargie.

Il n'a pas été réévalué depuis la date de soutenance.

Il est soumis à la propriété intellectuelle de l'auteur. Ceci implique une obligation de citation et de référencement lors de l'utilisation de ce document.

D'autre part, toute contrefaçon, plagiat, reproduction illicite encourt une poursuite pénale.

Contact au SICD1 de Grenoble : thesebum@ujf-grenoble.fr

\section{LIENS}

Code de la Propriété Intellectuelle. articles L 122. 4 Code de la Propriété Intellectuelle. articles L 335.2- L 335.10 http://www.cfcopies.com/juridique/droit-auteur http://www.culture.gouv.fr/culture/infos-pratiques/droits/protection.htm 
UNIVERSITE JOSEPH FOURIER

FACULTE DE MEDECINE DE GRENOBLE

Année : 2015

Relation avec les atteintes du champ visuel et aptitude diagnostique des mesures de la couche des fibres optiques et de la tête du nerf optique en OCT Spectral-Domain

THESE

PRESENTEE POUR L'OBTENTION DU DOCTORAT EN MEDECINE

DIPLÔME D’ETAT

POLLET-VILLARD Frédéric

Né le 24 Juillet 1985

A Villeurbanne (69)

THESE SOUTENUE PUBLIQUEMENT A LA FACULTE DE MEDECINE DE GRENOBLE*

Le 19 Mars 2015

\section{DEVANT LE JURY COMPOSE DE}

Président du jury : Monsieur le Professeur Jean Paul ROMANET

Directeur de thèse : Monsieur le Professeur Florent APTEL

Membres :

Monsieur le Professeur Christophe CHIQUET

Monsieur le Professeur Alain VIGHETTO

*La Faculté de Médecine de Grenoble n'entend donner aucune approbation ni improbation aux opinions émises dans les thèses ; ces opinions sont considérées comme propres à leurs auteurs. 
UNIVERSITE JOSEPH FOURIER

FACULTE DE MEDECINE DE GRENOBLE

Année : 2015

Relation avec les atteintes du champ visuel et aptitude diagnostique des mesures de la couche des fibres optiques et de la tête du nerf optique en OCT Spectral-Domain

THESE

PRESENTEE POUR L'OBTENTION DU DOCTORAT EN MEDECINE

DIPLÔME D’ETAT

POLLET-VILLARD Frédéric

Né le 24 Juillet 1985

A Villeurbanne (69)

THESE SOUTENUE PUBLIQUEMENT A LA FACULTE DE MEDECINE DE GRENOBLE*

Le 19 Mars 2015

DEVANT LE JURY COMPOSE DE

Président du jury : Monsieur le Professeur Jean Paul ROMANET

Directeur de thèse : Monsieur le Professeur Florent APTEL

Membres :

Monsieur le Professeur Christophe CHIQUET

Monsieur le Professeur Alain VIGHETTO

*La Faculté de Médecine de Grenoble n'entend donner aucune approbation ni improbation aux opinions émises dans les thèses; ces opinions sont considérées comme propres à leurs auteurs. 


\section{Tables des matières}

1. Liste des enseignants à l'UFR de Médecine de Grenoble

Page 3

2. Remerciements

Page 7

3. Serment d'Hippocrate

Page 12

4. Article de thèse

Page 13

5. Figures et tableaux de l'article de thèse

Page 41

6. Résumé en français de la thèse et mots clés

Page 50 


\section{UFR de Médecine de Grenoble}

\section{Université
Joseph Fourier \\ MEDECINE}

DOMAINE DE LA MERCI

38706 LA TRONCHE CEDEX - France

TEL : $+33(0) 476637144$

FAX : $+33(0) 476637170$

$\underline{\text { Affaire suivie par Marie-Lise GALINDO } \quad \text { sp-medecine-pharmacie@ujf-grenoble.fr }}$

Doyen de la Faculté : M. le Pr. Jean Paul ROMANET

Année 2014-2015

ENSEIGNANTS A L'UFR DE MEDECINE

\begin{tabular}{|c|c|c|}
\hline CORPS & NOM-PRENOM & Discipline universitaire \\
\hline PU-PH & ALBALADEJO Pierre & Anesthésiologie réanimation \\
\hline PU-PH & APTEL Florent & Ophtalmologie \\
\hline PU-PH & ARVIEUX-BARTHELEMY Catherine & chirurgie générale \\
\hline PU-PH & BALOSSO Jacques & Radiothérapie \\
\hline PU-PH & BARRET Luc & Médecine légale et droit de la santé \\
\hline PU-PH & BENHAMOU Pierre Yves & Endocrinologie, diabète et maladies métaboliques \\
\hline PU-PH & BERGER François & Biologie cellulaire \\
\hline PU-PH & BETTEGA Georges & Chirurgie maxillo-faciale, stomatologie \\
\hline MCU-PH & BIDART-COUTTON Marie & Biologie cellulaire \\
\hline MCU-PH & BOISSET Sandrine & Agents infectieux \\
\hline PU-PH & BONAZ Bruno & Gastro-entérologie, hépatologie, addictologie \\
\hline MCU-PH & BONNETERRE Vincent & Médecine et santé au travail \\
\hline PU-PH & BOSSON Jean-Luc & $\begin{array}{c}\text { Biostatiques, informatique médicale et } \\
\text { technologies de communication }\end{array}$ \\
\hline MCU-PH & BOTTARI Serge & Biologie cellulaire \\
\hline PU-PH & BOUGEROL Thierry & Psychiatrie d'adultes \\
\hline PU-PH & BOUILLET Laurence & Médecine interne \\
\hline MCU-PH & BOUZAT Pierre & Réanimation \\
\hline PU-PH & BRAMBILLA Christian & Pneumologie \\
\hline PU-PH & BRAMBILLA Elisabeth & Anatomie et cytologie pathologiques \\
\hline MCU-PH & BRENIER-PINCHART Marie Pierre & Parasitologie et mycologie \\
\hline PU-PH & BRICAULT Ivan & Radiologie et imagerie médicale \\
\hline PU-PH & BRICHON Pierre-Yves & Chirurgie thoracique et cardio- vasculaire \\
\hline MCU-PH & BRIOT Raphaël & Thérapeutique, médecine d'urgence \\
\hline PU-PH & CAHN Jean-Yves & Hématologie \\
\hline MCU-PH & CALLANAN-WILSON Mary & Hématologie, transfusion \\
\hline PU-PH & CARPENTIER Françoise & Thérapeutique, médecine d'urgence \\
\hline PU-PH & CARPENTIER Patrick & Chirurgie vasculaire, médecine vasculaire \\
\hline PU-PH & CESBRON Jean-Yves & Immunologie \\
\hline PU-PH & CHABARDES Stephan & Neurochirurgie \\
\hline
\end{tabular}




\begin{tabular}{|c|c|c|}
\hline PU-PH & CHABRE Olivier & Endocrinologie, diabète et maladies métaboliques \\
\hline PU-PH & CHAFFANJON Philippe & Anatomie \\
\hline PU-PH & CHAVANON Olivier & Chirurgie thoracique et cardio- vasculaire \\
\hline PU-PH & CHIQUET Christophe & Ophtalmologie \\
\hline PU-PH & CINQUIN Philippe & $\begin{array}{l}\text { Biostatiques, informatique médicale et } \\
\text { technologies de communication }\end{array}$ \\
\hline PU-PH & COHEN Olivier & $\begin{array}{l}\text { Biostatiques, informatique médicale et } \\
\text { technologies de communication }\end{array}$ \\
\hline PU-PH & COUTURIER Pascal & Gériatrie et biologie du vieillissement \\
\hline PU-PH & CRACOWSKI Jean-Luc & $\begin{array}{l}\text { Pharmacologie fondamentale, pharmacologie } \\
\text { clinique }\end{array}$ \\
\hline PU-PH & DE GAUDEMARIS Régis & Médecine et santé au travail \\
\hline PU-PH & DEBILLON Thierry & Pédiatrie \\
\hline MCU-PH & DECAENS Thomas & Gastro-entérologie, Hépatologie \\
\hline PU-PH & DEMATTEIS Maurice & Addictologie \\
\hline PU-PH & DEMONGEOT Jacques & $\begin{array}{c}\text { Biostatiques, informatique médicale et } \\
\text { technologies de communication }\end{array}$ \\
\hline MCU-PH & DERANSART Colin & Physiologie \\
\hline PU-PH & DESCOTES Jean-Luc & Urologie \\
\hline MCU-PH & DETANTE Olivier & Neurologie \\
\hline MCU-PH & DIETERICH Klaus & Génétique et procréation \\
\hline MCU-PH & DOUTRELEAU Stéphane & Physiologie \\
\hline MCU-PH & DUMESTRE-PERARD Chantal & Immunologie \\
\hline PU-PH & EPAULARD Olivier & Maladies Infectieuses et Tropicales \\
\hline PU-PH & ESTEVE François & Biophysique et médecine nucléaire \\
\hline MCU-PH & EYSSERIC Hélène & Médecine légale et droit de la santé \\
\hline PU-PH & FAGRET Daniel & Biophysique et médecine nucléaire \\
\hline PU-PH & FAUCHERON Jean-Luc & chirurgie générale \\
\hline MCU-PH & FAURE Julien & Biochimie et biologie moléculaire \\
\hline PU-PH & FERRETTI Gilbert & Radiologie et imagerie médicale \\
\hline PU-PH & FEUERSTEIN Claude & Physiologie \\
\hline PU-PH & FONTAINE Éric & Nutrition \\
\hline PU-PH & FRANCOIS Patrice & $\begin{array}{c}\text { Epidémiologie, économie de la santé et } \\
\text { prévention }\end{array}$ \\
\hline PU-PH & GARBAN Frédéric & Hématologie, transfusion \\
\hline PU-PH & GAUDIN Philippe & Rhumatologie \\
\hline PU-PH & GAVAZZI Gaétan & Gériatrie et biologie du vieillissement \\
\hline PU-PH & GAY Emmanuel & Neurochirurgie \\
\hline MCU-PH & GILLOIS Pierre & $\begin{array}{c}\text { Biostatiques, informatique médicale et } \\
\text { technologies de communication }\end{array}$ \\
\hline PU-PH & GODFRAIND Catherine & $\begin{array}{l}\text { Anatomie et cytologie pathologiques } \\
\text { (type clinique) }\end{array}$ \\
\hline MCU-PH & GRAND Sylvie & Radiologie et imagerie médicale \\
\hline PU-PH & GRIFFET Jacques & Chirurgie infantile \\
\hline MCU-PH & GUZUN Rita & $\begin{array}{l}\text { Endocrinologie, diabétologie, nutrition, } \\
\text { éducation thérapeutique }\end{array}$ \\
\hline PU-PH & HALIMI Serge & Nutrition \\
\hline PU-PH & HENNEBICQ Sylviane & Génétique et procréation \\
\hline
\end{tabular}




\begin{tabular}{|c|c|c|}
\hline PU-PH & HOFFMANN Pascale & Gynécologie obstétrique \\
\hline PU-PH & HOMMEL Marc & Neurologie \\
\hline PU-PH & JOUK Pierre-Simon & Génétique \\
\hline PU-PH & JUVIN Robert & Rhumatologie \\
\hline PU-PH & KAHANE Philippe & Physiologie \\
\hline PU-PH & KRACK Paul & Neurologie \\
\hline PU-PH & KRAINIK Alexandre & Radiologie et imagerie médicale \\
\hline PU-PH & LABARERE José & Epidémiologie ; Eco. de la Santé \\
\hline PU-PH & LANTUEJOUL Sylvie & Anatomie et cytologie pathologiques \\
\hline MCU-PH & LAPORTE François & Biochimie et biologie moléculaire \\
\hline MCU-PH & LARDY Bernard & Biochimie et biologie moléculaire \\
\hline MCU-PH & LARRAT Sylvie & Bactériologie, virologie \\
\hline MCU-PH & LAUNOIS-ROLLINAT Sandrine & Physiologie \\
\hline PU-PH & LECCIA Marie-Thérèse & Dermato-vénéréologie \\
\hline PU-PH & LEROUX Dominique & Génétique \\
\hline PU-PH & LEROY Vincent & Gastro-entérologie, hépatologie, addictologie \\
\hline PU-PH & LETOUBLON Christian & chirurgie générale \\
\hline PU-PH & LEVY Patrick & Physiologie \\
\hline MCU-PH & LONG Jean-Alexandre & Urologie \\
\hline PU-PH & MACHECOURT Jacques & Cardiologie \\
\hline PU-PH & MAGNE Jean-Luc & Chirurgie vasculaire \\
\hline MCU-PH & MAIGNAN Maxime & Thérapeutique, médecine d'urgence \\
\hline PU-PH & MAITRE Anne & Médecine et santé au travail \\
\hline MCU-PH & MALLARET Marie-Reine & $\begin{array}{c}\text { Epidémiologie, économie de la santé et } \\
\text { prévention }\end{array}$ \\
\hline MCU-PH & MARLU Raphaël & Hématologie, transfusion \\
\hline MCU-PH & MAUBON Danièle & Parasitologie et mycologie \\
\hline PU-PH & MAURIN Max & Bactériologie - virologie \\
\hline MCU-PH & MCLEER Anne & Cytologie et histologie \\
\hline PU-PH & MERLOZ Philippe & Chirurgie orthopédique et traumatologie \\
\hline PU-PH & MORAND Patrice & Bactériologie - virologie \\
\hline PU-PH & MOREAU-GAUDRY Alexandre & $\begin{array}{c}\text { Biostatiques, informatique médicale et } \\
\text { technologies de communication }\end{array}$ \\
\hline PU-PH & MORO Elena & Neurologie \\
\hline PU-PH & MORO-SIBILOT Denis & Pneumologie \\
\hline MCU-PH & MOUCHET Patrick & Physiologie \\
\hline PU-PH & MOUSSEAU Mireille & Cancérologie \\
\hline PU-PH & MOUTET François & $\begin{array}{c}\text { Chirurgie plastique, reconstructrice et } \\
\text { esthétique, brûlogie }\end{array}$ \\
\hline MCU-PH & PACLET Marie-Hélène & Biochimie et biologie moléculaire \\
\hline PU-PH & PALOMBI Olivier & Anatomie \\
\hline PU-PH & PARK Sophie & Hémato - transfusion \\
\hline PU-PH & PASSAGGIA Jean-Guy & Anatomie \\
\hline PU-PH & PAYEN DE LA GARANDERIE Jean-François & Anesthésiologie réanimation \\
\hline MCU-PH & PAYSANT François & Médecine légale et droit de la santé \\
\hline
\end{tabular}




\begin{tabular}{|c|c|c|}
\hline MCU-PH & PELLETIER Laurent & Biologie cellulaire \\
\hline PU-PH & PELLOUX Hervé & Parasitologie et mycologie \\
\hline PU-PH & PEPIN Jean-Louis & Physiologie \\
\hline PU-PH & PERENNOU Dominique & Médecine physique et de réadaptation \\
\hline PU-PH & PERNOD Gilles & Médecine vasculaire \\
\hline PU-PH & PIOLAT Christian & Chirurgie infantile \\
\hline PU-PH & PISON Christophe & Pneumologie \\
\hline PU-PH & PLANTAZ Dominique & Pédiatrie \\
\hline PU-PH & POLACK Benoît & Hématologie \\
\hline PU-PH & POLOSAN Mircea & Psychiatrie d'adultes \\
\hline PU-PH & PONS Jean-Claude & Gynécologie obstétrique \\
\hline PU-PH & RAMBEAUD Jacques & Urologie \\
\hline MCU-PH & RAY Pierre & Génétique \\
\hline PU-PH & REYT Émile & Oto-rhino-laryngologie \\
\hline MCU-PH & RIALLE Vincent & $\begin{array}{l}\text { Biostatiques, informatique médicale et } \\
\text { technologies de communication }\end{array}$ \\
\hline PU-PH & RIGHINI Christian & Oto-rhino-laryngologie \\
\hline PU-PH & ROMANET J. Paul & Ophtalmologie \\
\hline MCU-PH & ROUSTIT Matthieu & $\begin{array}{c}\text { Pharmacologie fondamentale, pharmaco } \\
\text { clinique, addictologie }\end{array}$ \\
\hline MCU-PH & ROUX-BUISSON Nathalie & Biochimie, toxicologie et pharmacologie \\
\hline PU-PH & SARAGAGLIA Dominique & Chirurgie orthopédique et traumatologie \\
\hline MCU-PH & SATRE Véronique & Génétique \\
\hline PU-PH & SAUDOU Frédéric & Biologie Cellulaire \\
\hline PU-PH & SCHMERBER Sébastien & Oto-rhino-laryngologie \\
\hline PU-PH & SCHWEBEL-CANALI Carole & Réanimation médicale \\
\hline PU-PH & SCOLAN Virginie & Médecine légale et droit de la santé \\
\hline MCU-PH & SEIGNEURIN Arnaud & $\begin{array}{c}\text { Epidémiologie, économie de la santé et } \\
\text { prévention }\end{array}$ \\
\hline PU-PH & STAHL Jean-Paul & Maladies infectieuses, maladies tropicales \\
\hline PU-PH & STANKE Françoise & Pharmacologie fondamentale \\
\hline MCU-PH & STASIA Marie-José & Biochimie et biologie moléculaire \\
\hline PU-PH & TAMISIER Renaud & Physiologie \\
\hline PU-PH & TONETTI Jérôme & Chirurgie orthopédique et traumatologie \\
\hline PU-PH & TOUSSAINT Bertrand & Biochimie et biologie moléculaire \\
\hline PU-PH & VANZETTO Gérald & Cardiologie \\
\hline PU-PH & VUILLEZ Jean-Philippe & Biophysique et médecine nucléaire \\
\hline PU-PH & WEIL Georges & $\begin{array}{c}\text { Epidémiologie, économie de la santé et } \\
\text { prévention }\end{array}$ \\
\hline PU-PH & ZAOUI Philippe & Néphrologie \\
\hline PU-PH & ZARSKI Jean-Pierre & Gastro-entérologie, hépatologie, addictologie \\
\hline
\end{tabular}


A mon Papé,

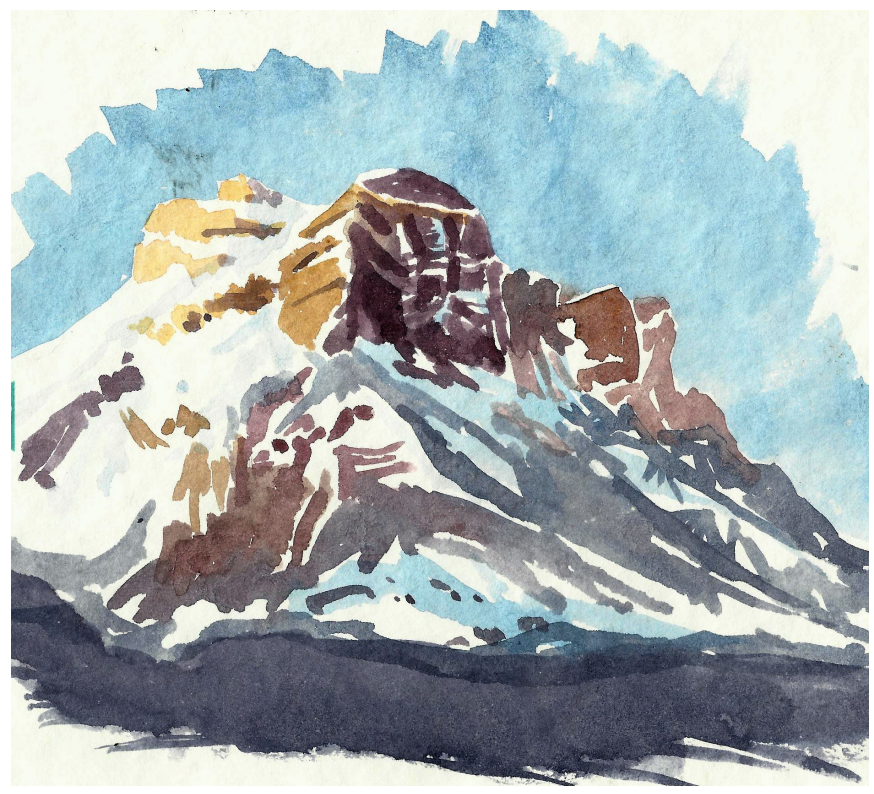


A Monsieur le Professeur Romanet, pour votre investissement dans notre formation universitaire, votre supervision bienveillante dans les réunions recherche, aux urgences ou dans le service.

A Monsieur le Professeur Chiquet, pour votre investissement dans notre formation clinique médicale et chirurgicale. Vous nous façonnez, tel un tailleur de pierre, pour obtenir à partir de l'épure le diamant qui se cache en chacun.

A Monsieur le Professeur Aptel : ton encadrement dans ce travail a été crucial, serein et agréable. L'exemple de précision, concision et d'organisation que tu m'as fourni m'a permis de progresser dans ma manière de travailler. Merci de m'avoir montrer la voie d'un travail de recherche clinique et de nous transmettre, de façon répétée, ta science, précise et exhaustive du glaucome, de son exploration et de ses traitements.

A Monsieur le Professeur Vighetto et au Professeur Caroline Tilikete : vous êtes mes parents et mentors de neuroophtalmologie. J'essaie chaque jour d'employer cet héritage à bon escient.

Monsieur Vighetto, vous combinez un respect absolu de l'Autre, un raffinement extrême et la somme considérable de toute science neurologique et ophtalmologique.

Caroline, je dois t'avouer que les nystagmus ont quand même encore des secrets pour moi! Ta disponibilité, le partage de tes réflexions, celui de ton raisonnement clinique et de ta passion pour ce métier me motive, rendent curieux et attentif !

Merci pour votre gentillesse, votre accueil chaleureux, et votre formation motivante.

Au Docteur Lucie Abouaf : tu rends simple et passionnante l'electrophy ! J'espère pourvoir suivre tes traces dans ce monde encore inconnu et te souhaite tout le bonheur du monde avec tes enfants.

Au Docteur Karine Palombi : tu m’as transmis l'ophtalmo-pédiatrie : la joie et l'anxiété !

Merci pour ces moments musicaux et chirurgicaux, la beauté de l'effet Schlieren ou d'un échange air-silicone, et de m'avoir ouvert au monde des petits. Que d'émerveillements à venir !

Au Docteur Diane Bernheim, pour le grand chirurgien que tu es devenue, pour ton compagnonnage chirurgical indispensable. Merci de nous soutenir, et de m'apprendre à écrire rond !

Merci aussi aux Docteurs Pierre Albinet, Jacques Faure, Marc-Michel Bru, Christian Noel, Sylvie Berthémy-Pellet, Vincent Jobert, Ruxandra Hera, Viviane Vinh, Pierre Pégourié, Dominique Satgé pour nous transmettre dans la bonne humeur votre passion pour tous les aspects de l'ophtalmologie.

Au Docteur José Boucraut : pour m’avoir hissé jusque « là », m’avoir appris beaucoup et dit que dans la vie, on commence par prendre plus que l'on ne donne, puis que l'on donne plus que l'on ne reçoit.

J'espère pouvoir un jour restituer ce savoir transmis. 
A Mamée et Mamythé.

A mes parents : vous êtes présents comme tout au long de ses 12 années folles. Maman bienveillante et souriante, et Papa auquel je ressemble plus qu'il ne le croit! Je vous aime.

A Françoise : l'arbre grandit ! A ma cousine qui m'expliquera peut être un jour pourquoi nous sommes si fous. A mes cousins qui ont choisi des voies plus raisonnables. A Marie Jo et Eric, pour vos bons mots et reparties fines.

A mon grand Bro', qui m’a précédé toutes ces années durant ! Tu es là dans les moments qui comptent. Merci de m'avoir poussé vers l'ophtalmo et la qualité de vie ! J'espère qu'on construira une grande famille avec Roxana.

\section{A Tiphaine}

Tu es la depuis avant

Tu me supportes quand soirs, weekend et jours fériés je te délaisse

Tu me guides et me fais réfléchir !

On ne s'ennuie pas, tant patachon que libre du talon!

Je t'admire et je t'aime.

A Nadine, Bernard, Elodie et Rémi, Adeline et Jérôme, Mamily et Madeleine, Mamie Jo ainsi qu'à Arthur, Noémie, Gabriel et Clarisse. Pour m'accueillir dans la famille et nos temps libres partagés. J'espère que ces derniers seront plus nombreux et remplis.

A Georges, mon Wingman! Nous sommes complémentaires : tu aimes la chir, je suis plutôt med ; j'adore la neuroophta et la ped, tu préfères rétine et palpébral ; tu as une connaissance livresque insoupçonnée, je suis plutôt filling! Je ne peux que te souhaiter tout le bonheur du monde après avoir passé (déjà) 5 années avec toi !! Celle qui arrivera à te supporter sera comblée! Tu es le plus gentil des hommes que je connaisse, parfois trop!

Sois beau, grand, concis, et fier de toi ! Tu chantes la marseillaise comme personne : en

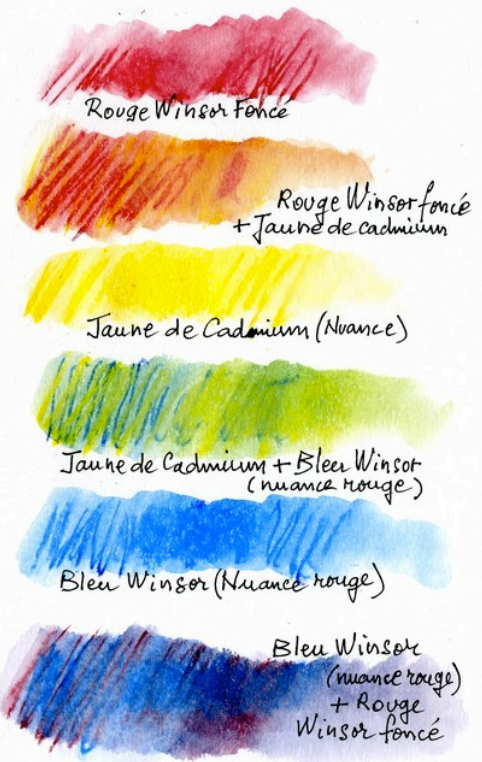
trompette ! « Docteur » Brin-de-thym, c'est pour bientôt : je te souhaite de trouver une place qui te convienne! On continuera d'apprendre ensemble, la cuisine française, le vin et la vie !

A Laurent B, parce que l'amitié n'a pas de faim (blague bidon !!) Quand est ce que tu te maries ?!

A Elodie D, mon secours en cas de rencontre de patient avec des trucs médicaux : Sans toi, l'Augmentin ne serait plus ce qu'il est! Merci de m'avoir rendu plus gentil!

A Thierry Zhou : le plus pervers des cointernes (ou bien ?) Légendaire : tes 8/10 en salle d'attente des urg, l'ANESTHESISTE !!, tes questions « intimes » et tes strabismes divergents (hypo ou exo selon les cas !) Tu m'as guidé lors de mes premiers pas, dans la bonne humeur, le sérieux et l'amitié ! Avoir Tristan t'a embelli. Merci Claire pour les chaussures assorties !

A Madame le Docteur Cécile Musson Rouchy pour avoir accepté de partager cette thèse, et pour la belle, souriante, pulpeuse, talentueuse et agréable ophtalmologiste que tu es devenue !

A Antoine Lesoin et à la Triplopie qui restera dans les mémoires ! Ton calme légendaire t’a valu des moments difficiles. Je l'estime au contraire ! Sois heureux entouré de toute ta famille.

A Christine, son alter ego, avec tout mon amour pour ton soutien et ton amitié !

A Jules, pour nous faire sourire et ressembler de plus en plus à ton père

A Mathilde Gallice : je me souviendrai toujours ton cours sur le prélèvement de cornée ! Je ne peux depuis ce jour que tarir d'éloge à ton égard : ta gentillesse, ta disponibilité, ton pragmatisme et le puits de science accumulé font que j'aimerai bien te ressembler! Je te souhaite d'être comblée : vive Ambroise ! A Caroline Dupuy : on ne s'est pas beaucoup croisé depuis nos débuts communs mais j'ai pris un peu de retard! A très vite!

A Marco, le plus rigolo et le plus sportif ! ALBERTPOWER ! A Nischal pour sa zenitude

A Rachel pour être presque parfaite! Merci de nous faire rire, de ta bonne humeur et du reste.

A Lenore « comme la lessive » pour l'accent du sud et pour dépoussiérer un peu les vieilles habitudes. J'espère que tu prends bien tes marques parmi nous.

A Julie Kosacki, entre Coksacades et accessoires de mode : Bref, l'incarnation du tumblr : l'interne d'ophtalmo débarque au self !

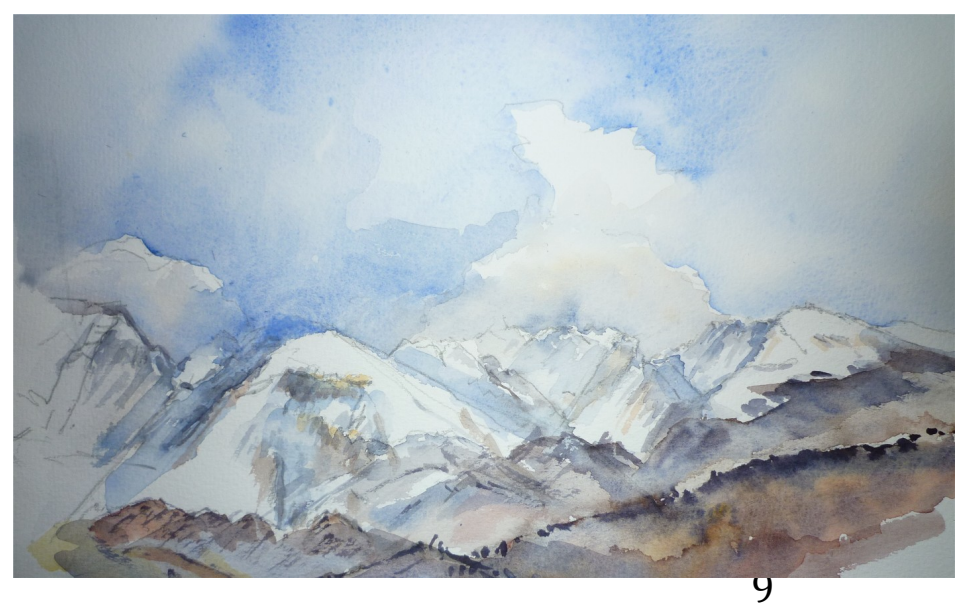


A Olivier Gavard et Adriane Mailhac, les Lauren Bacall et Humphrey Bogart de l'ophtalmologie ! Dandy! A mes 2 petites Padawans : vous êtes les plus jolies et les plus brillantes! Ne changez pas d'un pouce et surtout: profitez, aimez, et épanouissez vous!

A Bruno qui nous a quitté pour ces petites lames! A Julie Blot pour que tu t'épanouisses en ophtalmo, sans stress! A FX Guerriot - geek attitude - tu deviendras grand et talentueux! A Nico - 2d geek attitude- pour ton investissement et ta motivation. A Kim TST pour piquer des fards au premier verre!

Et à Oualid, Medhi, Julie D, Lucile, Pierre et les talentueux suivants pour que vous aimiez l'ophtalmologie !

A Magali pour ton dynamisme, Eva pour ton swing JROesque, AuréCombédeL pour ton pragmatisme, Tiffany pour ton sourire, Elisabeth Renard pour les CXL et KT SUR l'œil (et le relativisme quand on devient grand) A Ralitsa, pour l'ATROPINE !! mais aussi la neuro-ophtalmo !

A Lucile Arragain, Etienne Berta, Claire Chevelle, Jeremy Cognault, Jérôme Collona d'Istria (et son bracmarus) pour ces débuts d'internat fantasques!

Au docteur Antoine Baudet pour ses avis toujours éclairés

Aux plus »grands » :

Au Docteur Matthieu Tonini pour le télémark, les mercredi de l'ophtalmoloski, et la mauvaise foi ! Je crois que ça résume bien tout ça, hormis les phacos, les sorties, les filles, la corse et tout ce que l'on taira! Profites bien d'Anael, et n'oublie pas : les femmes ont toujours raison!

Au grand docteur Hafid Khayi ! un peu ronchon mais pas bidochon, tu es le phacoman le plus rapide de l'ouest! Merci pour ces débuts à tes cotés! Je vous espère heureux avec Nassima! Et n'oublie pas la tablette de chocolat (Abercromby forever).

A la merveilleuse Leslie NOYELLES alias « chef piou »: pour ton rire, tes coups de pince sur les doigts et tout le reste! L'esthétisme et la beauté dans les mains d'un fixateur d'os! Mes meilleurs vœux avec (on connaît pas encore son prénom !) en espérant que les nuits sans dormir à pouponner te ravissent. La bise à RAMOU !

Au futur professeur Damien Biotti pour nous avoir livré les secrets de l'oculomotricité, et nous passionner pour le syndrome du sinus silencieux!

Au Professeur Orgiazzi et au Docteur Cristina Vardanian pour la passion de l'orbitopathie basedowienne.

Au docteur Aurélie Vigneron pour sa collaboration et ses yeux bleu, ainsi que ceux de Virginie Lafontaine !

A Mazen Assad pour les BAT et mes débuts en ORL!

Au Docteur Fonlupt pour sa bienveillance et sa vivacité d'esprit (autant que pour ses histoires de bloc !)

Au docteur Moyenin pour nous avoir « débrouillé » de l'ophtalmologie.

Aux copains neurologues grenoblois, avec qui j'apprends tous les jours :

-Sébastien Gonthier : tout est parti de toi ! mon premier stilling duane que j'ai mis du temps à comprendre ! J'espère qu'on pourra continuer ensemble, c'est un plaisir renouvelé à chaque fois ! Vous faites la paire avec Auré-Elise.

-Docteur Nicourt-Nilong : toi aussi, tu es neurologue! Soyez heureux et profitez en avec Seb !

-Docteur Matthieu Vaillant : j'ai été triste de te voir partir (c... de p...). Nous allons continuer à former le binôme de neuro-ophtalmo le plus cool du NORA !! Sans oublier de recruter les jeunes! Vive la ION, la skew et le WEBINO !

-Docteur Olivier Casez : c'est un plaisir de travailler avec toi et je l'espère partagé. Je n'entends que des choses bien sur toi! -Pauline Cuisenier : c'est un VI RADICULAIRE ! J'espère que tu apprécies encore les internes d'ophtalmo après tout ça ! un joli minois avec une tête bien faite!

- et aussi Monsieur Papassin, Mademoiselle Uginet, Madame FavreWiki et Maud Napol : la neuro-ophtalmo c'est fantastique !

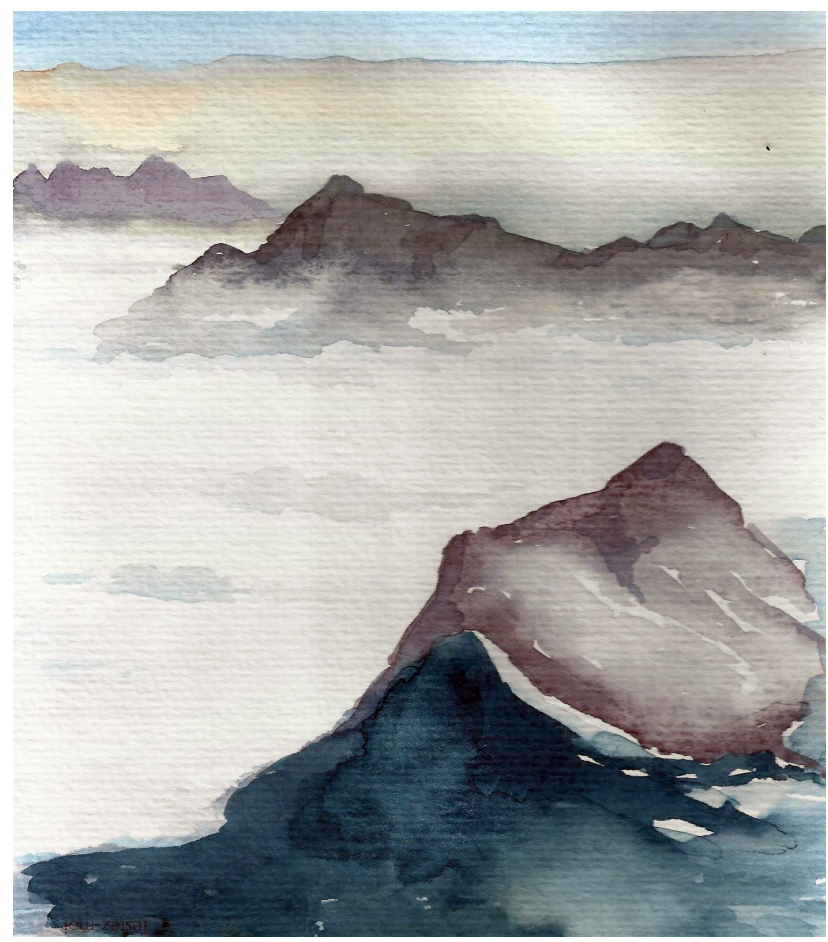




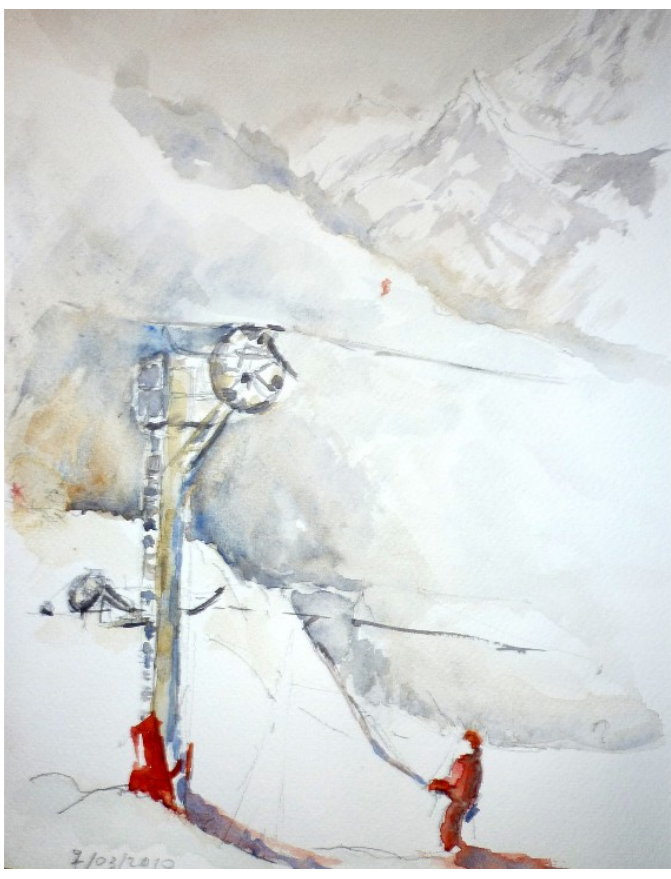

Aux copains neurologues lyonnais :

-Maud Esteban ou la reine de l'EMG et des trucs où on comprend rien (PRN quoi ?).

-Rebecca Salllit : en toi aussi sommeille une neuro-ophtalmologiste confirmé !

Tous mes vœux avec Ellie pour la suite ! (et venez nous voir dans les montagnes!)

-Steph Roggerone pour m'accompagner dans le plus beau des DU.

-Elodie Ong et Laure Gallay pour l'été merveilleux au 301 (et le pin's)

A tous les amis marseillais :

Floriane Guimond (et monsieur !), Laurie-Anne (et guillaume),

A ma DD (et monsieur Miramon), pour les heures de BU, les sous colles et tout le reste bien plus fun ! A Pripri : à quand le kite, l'habitable, et de nouveau le Brousse-à-la-banane? A la petite Cécile qui deviendra grande parmi les petits. Au grand professeur Nefzaoui : tu te souviens, le poly de physio ??

Mattei, futur dieu vivant de l'orthopédie. Continue de nous faire rire ! Marie Arthuis, la plus déjantée : le génie nait-il de la folie ? A Naima pour son virus de l'ophtalmo, A Marie Laure Blum pour son virus des voyages. Ainsi qu'à Perrine Savary (super co-assistante !) Amélie Ferdinand et Lulu Hoarau pour notre prochain road trip ! A Emeline Tabouret, reine du glioblastome, et Marjorie Kerzoncuf pour les soirées filles ! A Yvan Ledolley pour ton amour de la cardio et ton pragmatisme serein.

A Raphael Deslemps avec son violoncelle, A Raphaëlle Papillon avec sa raquette de tennis et son vélo ! A Lucie Gaide Chevronnet et Clément Dupuis avec Maxime

A l'EMEPS : Isabelle Berakdar, Patrick Benham, Baptiste Borwell, Maël Girard.

A l'EMSOC : Polona Savic, Alexander Indermark, Tin Nadarevic, Falk Schumacher, Matthew Strebel, Etienne Pittet

Et à ceux et celle qui font que chaque jour notre travail est possible, dans l'ombre la plupart du temps :

Laëtitia, Sandrine, Maité, Armelle (avec un synoptophore !!), Mme Bozon, Nathalie Reniaud, Joelle Coet, Véro,

Chantale, Marie-Ange, Fred, Elsa, Anaïs, Louise, Audrey, Monique, Martine Petit, Chonchon, Pierre, Pascal, Corinne, Michèle, Marie Ange, Coco et son cryo, Framboise et sa naropeine, Virginie, Emilie, Minipouce, Elodie

Catherine Tarantini, notre maman à tous et fournisseurs officiels de chocolat professoraux, Martine, Claudine (chl'), Mélanie en or, Miriam, Sonia, Nathalie, Ouaiba, Florence, Edith, Fabienne, Blandine (amatrice de tarte au citron et Wonderwoman de la pediatrie), Ellie, Fabien

Marie thé, Adeline, Monique, Delphine, Adeline, Martine, Ingrid, Sandra

Patricia Pontet, Céline, Muriel

Flore, Isabelle, Bernadette Rassat (secrétaire coordinatrice), Monique, Florence, Emma

Valérie, Monique, Florence, Florence De SaintEtienne, Maité Formaglio, Jenny, Sandrine et les autres que j'oublie !

Voici fini le temps de lire sans vous ennuyer lors de la présentation et des commentaires du jury. Le glaucome, le nerf optique, l'OCT, c'est bien! Mais il s'agit surtout de la consécration de 12 ans d'études, de 2 concours, de milliers d'heures en face de son bureau, de 8 déménagements, de larbinage ou jardinage à l'hôpital, d'engueulades et de rires, de joies devant la découverte du siècle (vive la neuro-immuno), de weekends où on aimerait bien être avec les copains et la famille, et surtout de vous, ainsi que nos patients - ceux qu'on aiment (qui rapporte des chocolats ou du vin), ceux qui nous remettent à notre place (leçon de vie) et ceux qu'on oubliera jamais (« on a tous notre petit cimetière personnel »).

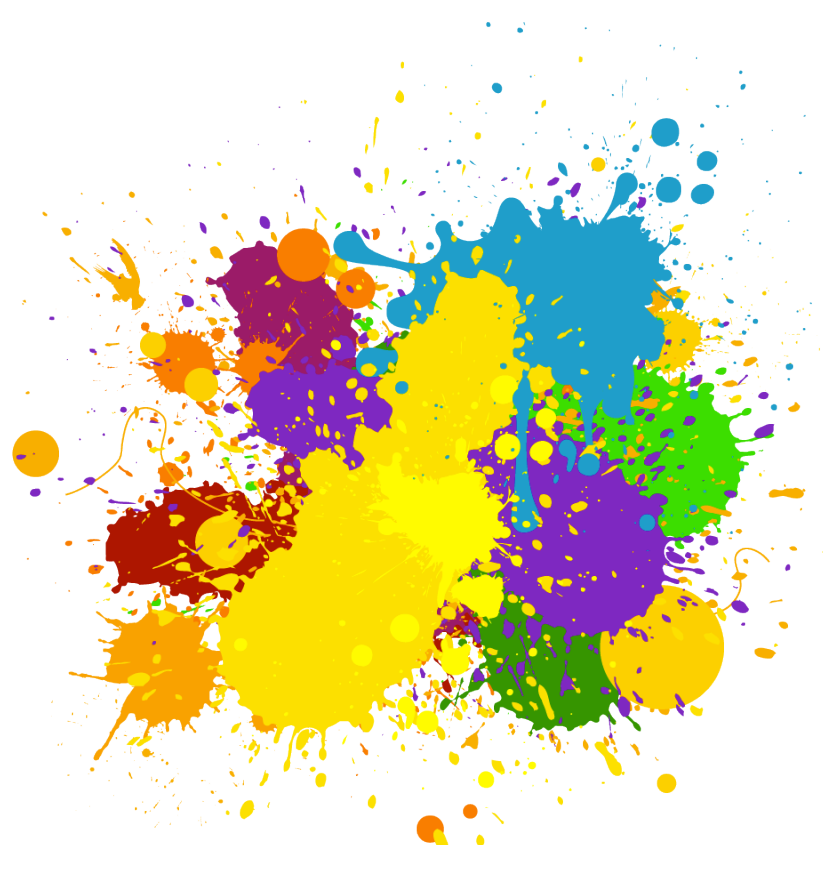




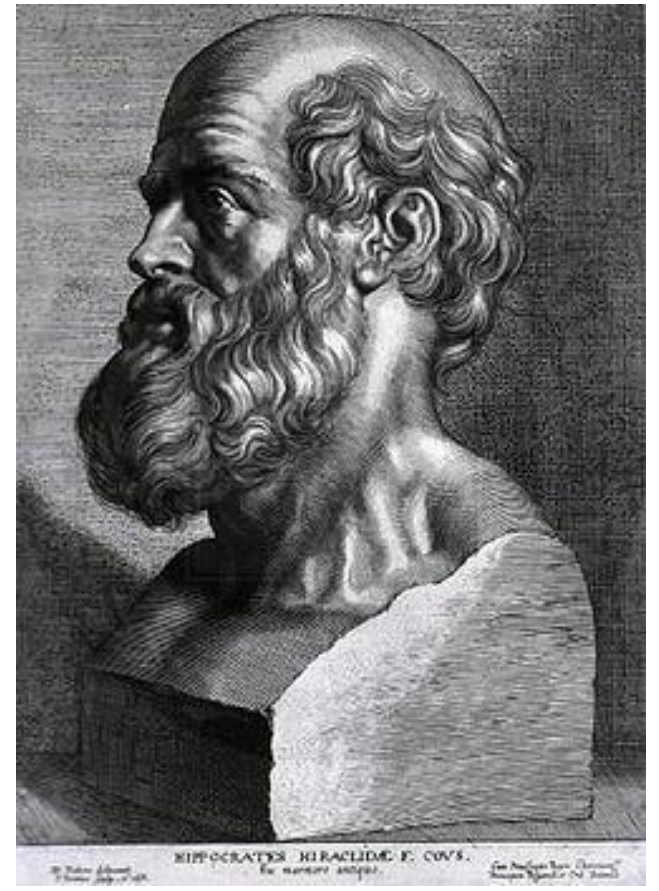

\section{SERMENT D'HIPPOCRATE}

En présence des Maîtres de cette Faculté, de mes chers condisciples et devant l'effigie d'HIPPOCRATE,

Je promets et je jure d'être fidèle aux lois de l'honneur et de la probité dans l'exercice de la Médecine.

Je donnerais mes soins gratuitement à l'indigent et n'exigerai jamais un salaire au dessus de mon travail. Je ne participerai à aucun partage clandestin d'honoraires.

Admis dans l'intimité des maisons, mes yeux n'y verront pas ce qui s'y passe ; ma langue taira les secrets qui me seront confiés et mon état ne servira pas à corrompre les mours, ni à favoriser le crime.

Je ne permettrai pas que des considérations de religion, de nation, de race, de parti ou de classe sociale viennent s'interposer entre mon devoir et mon patient.

Je garderai le respect absolu de la vie humaine.

Même sous la menace, je n'admettrai pas de faire usage de mes connaissances médicales contre les lois de l'humanité.

Respectueux et reconnaissant envers mes Maîtres, je rendrai à leurs enfants l'instruction que j'ai reçue de leurs pères.

Que les hommes m'accordent leur estime si je suis fidèle à mes promesses.

Que je sois couvert d'opprobre et méprisé de mes confrères si j'y manque. 
"Structure-function relationships with spectral-domain optical coherence tomography retinal nerve fiber layer and optic nerve head measurements

\section{Frédéric Pollet-Villard ${ }^{1}$, Christophe Chiquet ${ }^{1,2}$, Jean-Paul Romanet ${ }^{1}$, Christian Noel $^{1}$, Florent Aptel ${ }^{1,2}$}

1 - Department of Ophthalmology, University Hospital, CHU Grenoble, Grenoble, F-38043, France

2 - UJF-Grenoble 1, Grenoble, F-38041, France

2 - INSERM U1042, Hypoxia and Physiopathology Laboratory, Joseph Fourier University, Grenoble, F-38041, France

Financial support: Association de Recherche et de Formation en Ophtalmologie (ARFO).

None of the authors have any relevant financial interest to disclose.

Word count: 3904

Corresponding author and reprint requests:

Florent Aptel

Clinique Universitaire d'Ophtalmologie, Centre Hospitalo-universitaire de Grenoble, BP217, 38043 Grenoble cedex 09, FRANCE.

Tel.: + $33(0) 476795548$

Fax: + $33(0) 476767570$

E-mail: faptel@chu-grenoble.fr 


\begin{abstract}
Purpose: To evaluate the regional structure-function relationship between visual field sensitivity and retinal nerve fiber layer (RNFL) thickness and optic nerve head (ONH) measurements using spectral-domain optical coherence tomography (SD-OCT).
\end{abstract}

Methods: Prospective cross-sectional study conducted on patients with glaucoma, suspected glaucoma and healthy subjects. Eyes were tested on Cirrus OCT and standard achromatic perimetry. RNFL thickness of 12 peripapillary $30^{\circ}$ sectors, neuroretinal rim thickness extracted from 36 neuroretinal rim scans, and Bruch membrane opening minimum rim width $(\mathrm{BMO}-\mathrm{MRW})$ - a recently defined parameter - extracted from 36 neuroretinal rim scans were obtained. Correlations between peripapillary RNFL thickness, neuroretinal rim thickness, all six sectors of BMO-MRW and visual field sensitivity in the six corresponding areas were evaluated using logarithmic regression analysis. Receiver operating curve areas were calculated for each RNFL, ONH and macular ganglion cell analysis parameter.

Results: We included 142 eyes of 142 subjects. The correlations $\left(r^{2}\right)$ between RNFL thickness, Cirrus-based neuroretinal rim thickness, BMO-MRW and visual field sensitivity ranged from 0.07 to $0.60,0.15$ to 0.49 , and 0.24 to 0.66 , respectively. The structure-function correlations were stronger with BMO-MRW than with Cirrus-based neuroretinal rim thickness. The largest areas under the receiver operating curve were seen for rim area $(0.926$ [95\% confidence interval $0.875,0.977] ; p<.0001)$ in eyes with glaucoma and for average RNFL $(0.863[0.769,0.957] ; p<0.01)$ in eyes with suspected glaucoma.

Conclusions: The structure-function relationship was significantly stronger with BMOMRW than other ONH SD-OCT parameters. The best diagnostic capabilities were seen with rim area and average RNFL.

Key words: Glaucoma, Optical coherence tomography, Structure-function, Visual field. 


\section{INTRODUCTION}

The basic pathological change in glaucoma is the loss of retinal ganglion cells and their axons, resulting in a local and/or diffuse thinning of the retinal nerve fiber layer (RNFL) and of the neuroretinal rim, eventually leading to loss of visual function. ${ }^{1}$ Glaucoma diagnosis and follow-up of progression is often based on a combination of structural and functional assessments. Evaluation of structural loss has long been limited to a clinical qualitative examination of the optic nerve head (ONH) and RNFL. ${ }^{2,3}$ Imaging technologies introduced in the last decade now provide objective and quantitative measurements of the RNFL. ${ }^{4-7}$ Several studies have reported a significant relationship between structural damage, observed with different imaging methods, and functional damage, determined by standard achromatic perimetry. ${ }^{8-21}$

Optical coherence tomography (OCT) is a method that directly measures the RNFL and neuroretinal rim thickness. Previous studies have evaluated and compared the regional relationships between visual field sensitivity and RNFL thickness measured with OCT and with other imaging modalities such as scanning laser polarimetry or confocal scanning laser

ophthalmoscopy. ${ }^{8-21}$ Since algorithms allowing analysis of the neuroretinal rim thickness from SD-OCT ONH scans were recently developed and added to the devices' software, no studies have evaluated the regional relationships between SD-OCT-measured neuroretinal rim thickness and visual field sensitivity. Previous studies have found comparable or slightly lower capabilities of SD-OCT neuroretinal rim parameters provided by the currently available machines compared to RNFL parameters for glaucoma diagnosis. ${ }^{22-25}$ A new anatomical parameter describing the neuroretinal rim was recently proposed by Reis et al. and Chauhan et al. and consists of the minimum distance between the Bruch membrane opening and the internal limiting membrane (Bruch membrane opening minimal rim width, BMO-MRW). ${ }^{26,27}$ Compared to currently available SD-OCT neuroretinal thickness measurement methods, 
BMO-MRW has the advantage of taking into account the variable orientation of rim tissue in the $\mathrm{ONH}$.

The purpose of the current study was to evaluate and compare the regional and global structure-function relationship between visual field sensitivity and RNFL thickness and ONH measurements using SD-OCT, including the BMO-MRW parameter. We also evaluated and compared the diagnostic capabilities of the SD-OCT RNFL, ONH and macular ganglion cell analysis (GCA) measurements for distinguishing glaucomatous or suspected glaucomatous eyes from healthy eyes.

\section{METHODS}

\section{Patients}

We conducted a prospective investigation in a French university-affiliated hospital. The study followed the tenets of the declaration of Helsinki and has been prospectively approved by the Ethics Committee of the French Society of Ophthalmology (IRB 00008855 Société Française d'Ophtalmologie IRB\#1). All subjects provided both verbal and written informed consent. All study participants underwent a full ophthalmic examination, including objective and subjective refraction, slit-lamp biomicroscopy, intraocular pressure measurement with Goldmann tonometry, gonioscopy, dilated fundus examination by indirect ophthalmoscopy, central corneal thickness measurement and A-scan ultrasound biometry. Refraction was measured using an autorefractometer (AR-360 ; Nidek Co.,Ltd, Gamagori, Japan), gonioscopy using a Goldmann three-mirror lens (Goldman; Haag-Streit, Koenig, Switzerland) and pachymetry and A-scan ultrasound biometry system (OcuScanRxP; Alcon Inc, Fort Worth, TX, USA).

Inclusion criteria were age 18 years or older, best corrected visual acuity better than or equal to $20 / 40$, spherical refraction between -6.00 and $+3.00 \mathrm{D}$, open angles on gonioscopy, no 
retinal disease or nonglaucomatous neuropathy, and no intraocular surgery except for uncomplicated cataract surgery. One eye was selected randomly from each of 142 subjects: 55 with glaucoma, 47 with suspected glaucoma, and 40 healthy subjects. Glaucomatous eyes were defined as those with consecutive and reliable abnormal standard achromatic perimetry with abnormal Glaucoma Hemifield Test and pattern standard deviation outside $95 \%$ of normal limits, and optic nerve damage (asymmetric cup/disc ratio $>0.2$, rim thinning, notching, excavation or retinal nerve fiber layer defect). Suspected glaucomatous eyes were defined as those with optic nerve damage (asymmetric cup/disc ratio $>0.2$, rim thinning, notching, excavation or retinal nerve fiber layer defect) without repeatable abnormal standard achromatic perimetry results. Healthy eyes had intraocular pressure less than $22 \mathrm{mmHg}$ as shown by Goldman applanation tonometry, normal-appearing optic discs and no repeatable abnormal standard achromatic perimetry results.

\section{Measurements}

White-on-white standard achromatic perimetry was performed using a field analyser (Humphrey Visual Field Analyzer; Zeiss-Humphrey Systems, Dublin, CA, USA) using the C24-2 SITA-standard strategy. A reliable visual field test was defined as a less than $25 \%$ rate of fixation losses and fewer than $20 \%$ false-positive and false-negative results. The two points adjacent to the blind spot were excluded from the analysis. The 52 remaining points were grouped into six sectors, based on the topographic relationships between visual field locations and corresponding regions of the optic disc, as previously described by Garway-Heath et al. $^{28,29}$ (Figure 1). To calculate the mean total deviation of the six sectors, the decibel levels in each location of the total deviation field were converted to a linear scale (e.g., $0 \mathrm{~dB}$ converted to 1.0 and $30 \mathrm{~dB}$ to 0.001 ) before averaging the data within each sector. ${ }^{30}$ The averaged data were then converted back to decibel units. 
A commercially available spectral-domain OCT (Cirrus OCT, software version 6.0, Carl Zeiss Meditec, Inc, Dublin, CA, USA) was used in the study. The ONH and RNFL were imaged using the $200 \times 200$ protocol optic disc cube $(200$ horizontal scan lines, each consisting of 200 A-scans). Only well-focused, well-centered images, without eye movement and with a signal strength of $7 / 10$ or more were used. The RNFL parameters of the printout retained for the analysis were inferior, superior, nasal, temporal, average thickness, inter-eye symmetry, and retinal nerve fiber layer thickness for each of the twelve $30^{\circ}$ sectors. These $30^{\circ}$ sectors are centered on the acquired image frame axes (first sector $-15^{\circ}$ to $+15^{\circ}$, etc.). The $\mathrm{ONH}$ parameters of the printout retained for the analysis were rim area, disc area, average cup/disc ratio, vertical cup/disc ratio, and cup volume.

We collected the 256 retinal nerve fiber layer thicknesses of the TSNIT curve corresponding to the thicknesses extracted from the 256 A-scan along the path of the 3.46-mm calculation circle located around the optic disc by the Cirrus internal specific software. ${ }^{31}$ The Cirrus OCT software has the facility to scroll a cursor along the TSNIT curve, making the 256 values appear successively. These 256 values were grouped into six sectors, based on the relation between visual field and regions of the optic disc as described above: inferonasal $\left(231-270^{\circ}\right)$, inferotemporal $\left(271-310^{\circ}\right)$, temporal $\left(311-40^{\circ}\right)$, superotemporal $\left(41-80^{\circ}\right)$, superonasal $(81-$ $\left.120^{\circ}\right)$ and nasal $\left(121-230^{\circ}\right)$.

We collected 36 neuroretinal rim thickness measurements of the neuroretinal rim thickness curve. The Cirrus OCT software has the facility to scroll a cursor along the curve, making the 360 values appear successively. Thirty-six values were collected, at the $2^{\circ}, 12^{\circ}, 22^{\circ}$, etc., meridians, to avoid the boundaries of the above mentioned sectors $\left(231-270^{\circ}, 271-310^{\circ}\right.$, etc. $)$. These 36 values were then used to calculate the mean neuroretinal thickness into six sectors as described above. For example, the neuroretinal rim thickness in the superonasal sector (81$120^{\circ}$ ) is the mean of the neuroretinal thickness of the $82^{\circ}, 92^{\circ}, 102^{\circ}$ and $112^{\circ}$ meridians. 
We calculated 72 BMO-MRW from 36 cross-sectional ONH images (Figure 2). Thirty-six cross-sectional images of the $\mathrm{ONH}$ (B-scans centered on the optic nerve head center) were obtained at $0-180^{\circ}, 5-185^{\circ}, 10-190^{\circ}$, etc. meridians. The image-processing software ImageJ (Image processing and analysis in Java; National Institutes of Health, Bethesda, MD, USA) was used to analyze the images, which were viewed on a 21 -inch monitor $(1280 \times 1024 \times 24$ bits). Fourfold magnifications and rectangular selections were used to obtain 72 clear crosssectional images of the neuroretinal rim at the $0^{\circ}, 5^{\circ}, 10^{\circ}$, etc. meridians. The minimum distance between the Bruch membrane opening and the internal limiting membrane was measured from each of the 72 neuroretinal rim cross sections. The end of the Bruch membrane is automatically delineated by the Cirrus software and appeared as small black circle. The internal limiting membrane is automatically delineated by the Cirrus software and appeared as a red line. The first step was to perform a manual delineation of external black circle contours. The second step in the procedure was to locate the centroid of the defined surface. This was performed automatically by the software. The third step was to draw the line segment joining the centroid of the black circle and the internal limiting membrane, perpendicular to the internal limiting membrane, and thus being the minimum distance between the black dot and the internal limiting membrane. The last step was to measure the line segment, corresponding to the BMO-MRW. These 72 values were then used to calculate the mean BMO-MRW into six sectors as described above. For example, the neuroretinal rim thickness in the superonasal sector $\left(81-120^{\circ}\right)$ is the mean of the neuroretinal thickness of the $80^{\circ}, 85^{\circ}, 90^{\circ}, 95^{\circ}, 100^{\circ}, 105^{\circ}, 110^{\circ}, 115^{\circ}$ and $120^{\circ}$ meridians

The GCA was imaged using the $512 \times 128$ macular cube protocol. Only well-focused, wellcentered images, with no eye movement and with a signal strength of $7 / 10$ or greater were used. The parameters of the printout retained for the analysis were average thickness, minimal thickness and thickness for each of the six $60^{\circ}$ sectors. 

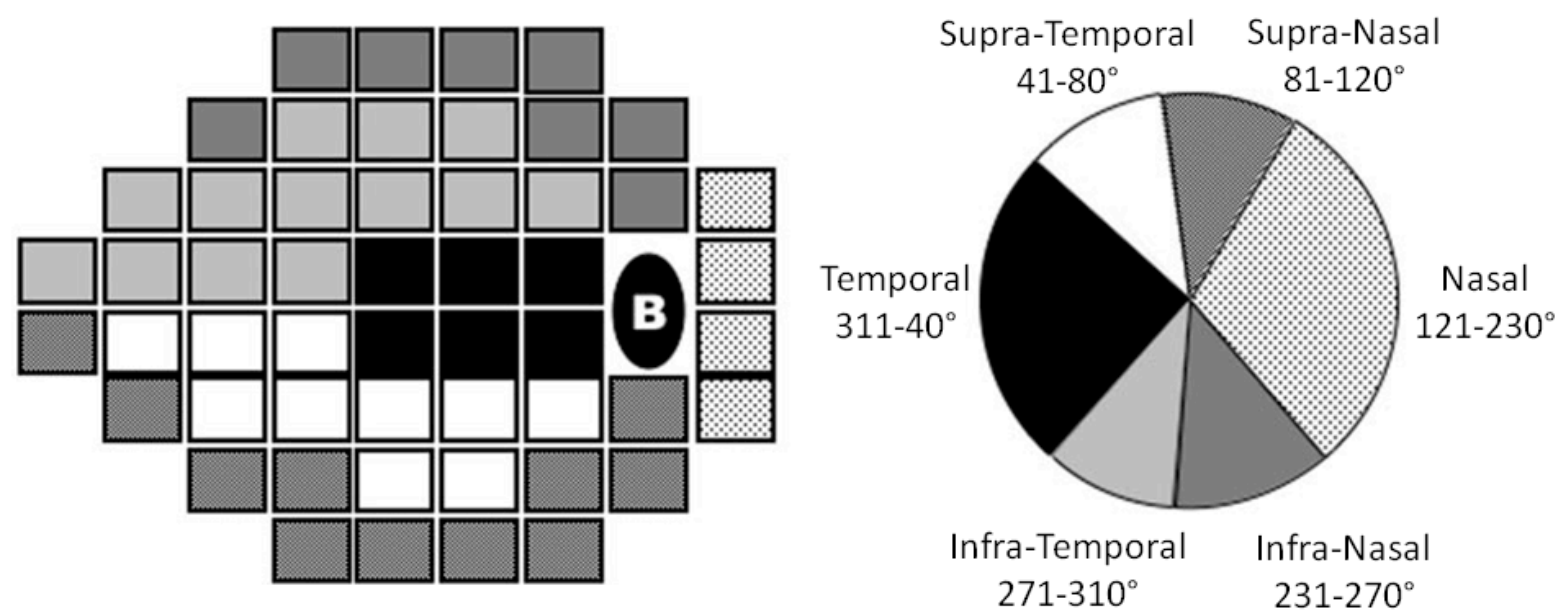

Figure 1. Division of the visual field and optic nerve head. Peripapillary retinal nerve fiber layer thickness sectors and corresponding visual field areas as established by Garway-Heath et al. ${ }^{28,29}$ 


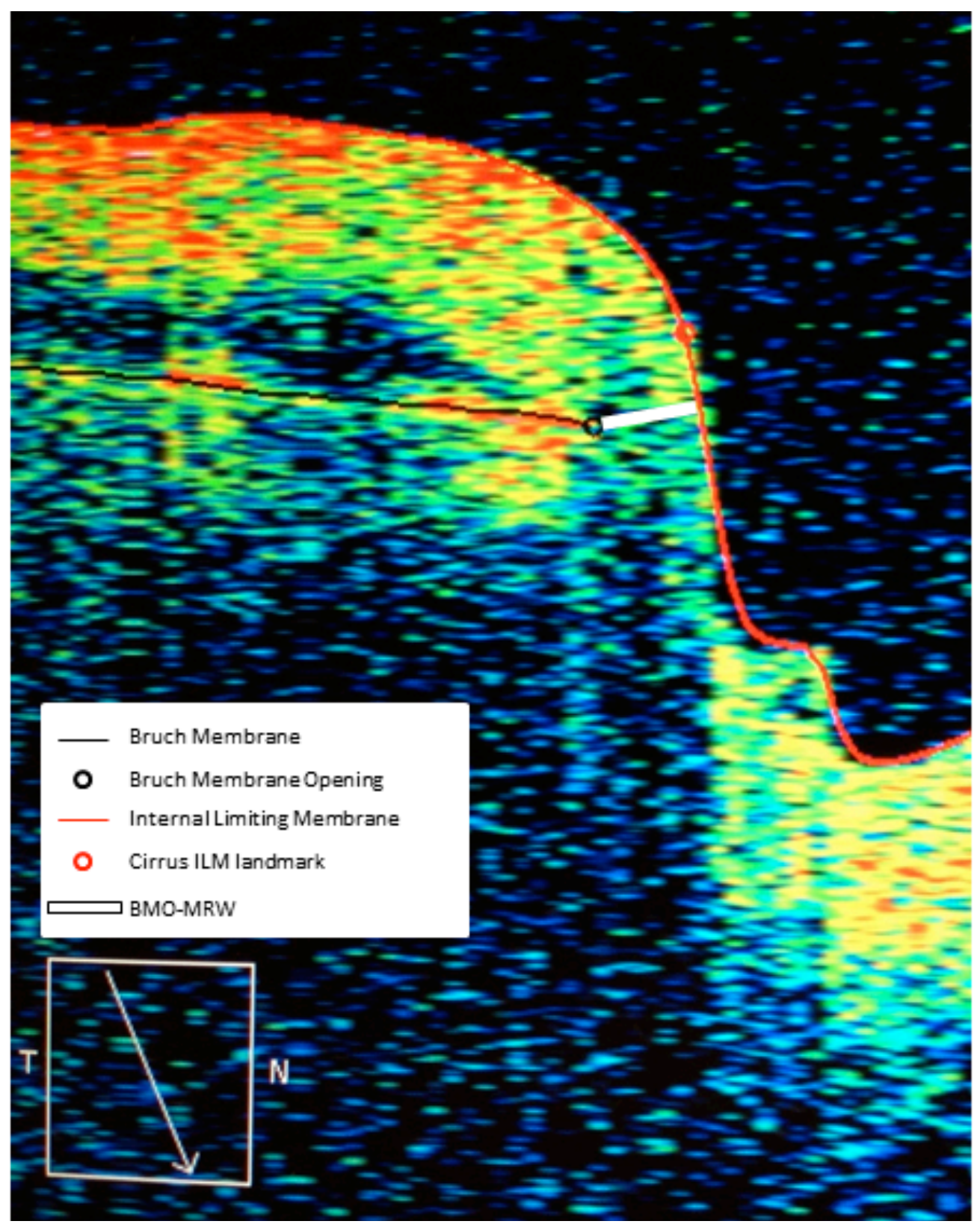

Figure 2. Example of cross-sectional optic nerve head image in the inferonasal sector. Bruch membrane, Bruch membrane opening, internal limiting membrane and internal limiting membrane landmark are automatically defined by the Cirrus internal specific software. Note the difference between the BMO-MRW distance and the neuroretinal rim thickness provided by the Cirrus software (distance between black and red dots). ILM, internal limiting membrane. BMO-MRW, Bruch membrane opening minimal rim width. 


\section{Data analysis}

Independent-sample $t$-tests, ANOVA and Mann-Whitney tests were used to compare means and percentages, depending of the normality of data distribution. Logarithmic $(y=a \cdot \ln (x)+b)$ regression analyses were performed to evaluate the relationship between visual field sensitivity and retinal nerve fiber layer or neuroretinal rim thickness in the six matching areas. Visual field sensitivity was the dependent variable. The statistical significance of $r$ was tested using a $t$-test. A two-tailed paired t-test was used to compare the strength of the association across structural parameters. Three pairs of correlations coefficients were used for each sector (in example, for one given structural sector and the corresponding visual field area, comparison of the RNFL-VF correlation coefficient to the NRR-VF correlation coefficient, comparison of the RNFL-VF correlation coefficient to the BMO-MRW-VF correlation coefficient, and comparison of the NRR-VF correlation coefficient to the BMO-MRW-VF correlation coefficient. Correlation coefficients were compared using the Fisher transform. The area under the receiver operator characteristic curve (AUROC) was used to assess the capability of each OCT parameter to differentiate between healthy and suspected glaucomatous eyes, and between healthy and glaucomatous eyes. An AUROC of 0.5 represents discrimination no better than chance; an area of 1 represents perfect discrimination. Differences between AUROCs among parameters were determined using the nonparametric method described by De Long et al. ${ }^{32}$ Statistical significance was set at $p \leq 0.05 . p$ values were statistically significant if lower than the mean statistical significance 0.05 divided by the number of comparisons performed. SPSS statistical software version 17.0 (SPSS Inc.,

Chicago, IL) was used for the analyses. 


\section{RESULTS}

\section{Patient characteristics}

A total of 142 eyes of 142 subjects were included ( 40 healthy eyes, 55 eyes with glaucoma and 47 eyes with suspected glaucoma). Their demographic, biometric and visual field data are shown in Table 1.

\begin{tabular}{|c|c|c|c|c|}
\hline & $\begin{array}{l}\text { Glaucoma } \\
(n=55)\end{array}$ & $\begin{array}{l}\text { Suspected } \\
\text { glaucoma } \\
(n=47)\end{array}$ & $\begin{array}{l}\text { Healthy } \\
(n=40)\end{array}$ & $\begin{array}{c}p \\
\text { (ANOVA) }\end{array}$ \\
\hline Age (years) mean $\pm \mathrm{SD}$ & $64.2 \pm 15.9$ & $61.9 \pm 14.2$ & $56.8 \pm 17.8$ & 0.04 \\
\hline Sex (male/female) & $26 / 29$ & $20 / 27$ & $19 / 21$ & 0.22 \\
\hline Spherical equivalent (D) mean $\pm \mathrm{SD}$ & $-1.31 \pm 2.2$ & $-.99 \pm 3.2$ & $-1.14 \pm 2.8$ & 0.90 \\
\hline Axial length $(\mathrm{mm})$ mean $\pm \mathrm{SD}$ & $23.2 \pm 1.1$ & $23.4 \pm 1.2$ & $23.4 \pm 1.0$ & 0.68 \\
\hline $\begin{array}{l}\mathrm{CCT}(\mu \mathrm{m}) \text { mean } \pm \mathrm{SD} \\
\text { Standard automated perimetry }(\mathrm{dB})\end{array}$ & $530 \pm 44$ & $532 \pm 36$ & $551 \pm 51$ & 0.06 \\
\hline - mean deviation $\pm \mathrm{SD}$ & $-8.28 \pm 8.64$ & $-1.56 \pm 2.22$ & $-1.60 \pm 3.02$ & $<0.01$ \\
\hline - pattern standard deviation \pm SD & $7.56 \pm 4.54$ & $2.78 \pm 2.03$ & $2.12 \pm 1.07$ & $<0.01$ \\
\hline
\end{tabular}

Table 1. Subjects characteristics. Demographic, biometric and visual field data in eyes with glaucoma, suspected glaucoma and healthy eyes. SD, standard deviation. CCT, central corneal thickness. Pairwise comparisons: Age (Glaucoma versus Suspected Glaucoma, $\mathrm{p}=0.45$; Glaucoma versus Healthy, $\mathrm{p}=0.03$; Suspected Glaucoma versus Healthy, $\mathrm{p}=0.12$ ), CCT (Glaucoma versus Suspected Glaucoma, $p=0.80$; Glaucoma versus Healthy, $p=0.03$; Suspected Glaucoma versus Healthy, $\mathrm{p}=0.04$ ), Mean Deviation (Glaucoma versus Suspected Glaucoma, $\mathrm{p}<0.001$; Glaucoma versus Healthy, $\mathrm{p}<0.001$; Suspected Glaucoma versus 
Healthy, $\mathrm{p}=0.92$ ) and Pattern Standard Deviation (Glaucoma versus Suspected Glaucoma, $\mathrm{p}<0.001$; Glaucoma versus Healthy, $\mathrm{p}<0.001$; Suspected Glaucoma versus Healthy, $\mathrm{p}=0.07$ ).

\section{Structure-function relationships}

Logarithmic regression parameters are presented in Table 2. Analyses showed a significant relationship between sectorial thickness and visual field sensitivity for most areas studied. The correlations $\left(\mathrm{r}^{2}\right)$ between RNFL thickness and visual field sensitivity ranged from 0.07 (nasal RNFL and corresponding visual field area) to 0.60 (inferotemporal RNFL and corresponding visual field area), between Cirrus-based neuroretinal rim thickness and visual field sensitivity ranged from 0.15 (nasal thickness and corresponding visual field area) to 0.49 (inferotemporal thickness and corresponding visual field area), and between BMO-MRW and visual field sensitivity ranged from 0.24 (nasal thickness and corresponding visual field area,) to 0.66 (inferotemporal thickness and corresponding visual field area). Logarithmic associations were strongest between the inferotemporal sector measurements and corresponding visual field areas, for the RNFL, neuroretinal rim and BMO-MRW measurements (Figure 3). In pairwise comparisons, logarithmic structure-function associations were stronger with the BMO-MRW measurements than with the neuroretinal rim measurements provided by the Cirrus software, for all 6 sectors $(\mathrm{p}<0.01)$. In pairwise comparisons, logarithmic structure-function associations were significantly stronger with the BMO-MRW measurements than with the RNFL measurements for the temporal, superonasal, nasal and inferotemporal sectors $(\mathrm{p}<0.01)$, and non-significantly different for the superotemporal and inferonasal sectors ( $\mathrm{p}=0.12$ and $\mathrm{p}=0.08$, respectively). 


\begin{tabular}{|c|c|c|c|}
\hline \multirow{2}{*}{$\begin{array}{c}\text { Peripapillary } \\
\text { sector }\end{array}$} & \multicolumn{3}{|c|}{ Logarithmic regression } \\
\hline & $\mathrm{r}^{2}$ & $p$ & $y=a * \ln (x)+b$ \\
\hline RNFL: & & & \\
\hline Temporal & 0.093 & 0.003 & $\mathrm{y}=9.9 \ln (\mathrm{x})-19.3$ \\
\hline Superotemporal & 0.495 & $<0.001$ & $y=15.8 \ln (x)-24.6$ \\
\hline Superonasal & 0.274 & $<0.001$ & $\mathrm{y}=11.2 \ln (\mathrm{x})-4.6$ \\
\hline Nasal & 0.065 & 0.005 & $y=9.51 \ln (x)-25.8$ \\
\hline Inferonasal & 0.263 & $<0.001$ & $y=15.4 \ln (x)-67.1$ \\
\hline Inferotemporal & 0.598 & $<0.001$ & $y=17.2 \ln (x)-77.5$ \\
\hline NRR: & & & \\
\hline Temporal & 0.401 & $<0.001$ & $y=8.70 \ln (x)-17.3$ \\
\hline Superotemporal & 0.457 & $<0.001$ & $y=8.58 \ln (x)-33.7$ \\
\hline Superonasal & 0.328 & $<0.001$ & $y=9.57 \ln (x)-25.6$ \\
\hline Nasal & 0.154 & 0.05 & $y=7.67 \ln (x)-3.44$ \\
\hline Inferonasal & 0.259 & $<0.001$ & $y=9.77 \ln (x)-26.4$ \\
\hline Inferotemporal & 0.494 & $<0.001$ & $\mathrm{y}=8.91 \ln (\mathrm{x})-41.1$ \\
\hline BMO-MRW: & & & \\
\hline Temporal & 0.457 & $<0.001$ & $\mathrm{y}=8.67 \ln (\mathrm{x})-8.50$ \\
\hline Superotemporal & 0.604 & $<0.001$ & $\mathrm{y}=8.88 \ln (\mathrm{x})-19.7$ \\
\hline Superonasal & 0.523 & $<0.001$ & $\mathrm{y}=8.75 \ln (\mathrm{x})-21.8$ \\
\hline Nasal & 0.241 & $<0.001$ & $y=6.41 \ln (x)-5.44$ \\
\hline Inferonasal & 0.460 & $<0.001$ & $\mathrm{y}=8.85 \ln (\mathrm{x})-23.6$ \\
\hline Inferotemporal & 0.658 & $<0.001$ & $y=10.1 \ln (x)-42.3$ \\
\hline
\end{tabular}


Table 2. Structure-function relationships. Logarithmic regression between Cirrus optical coherence tomography-measured retinal nerve fiber layer thickness, neuroretinal rim thickness and Bruch membrane opening minimum rim width in the six peripapillary sectors and visual field sensitivity $(\mathrm{dB})$ in the six corresponding areas.
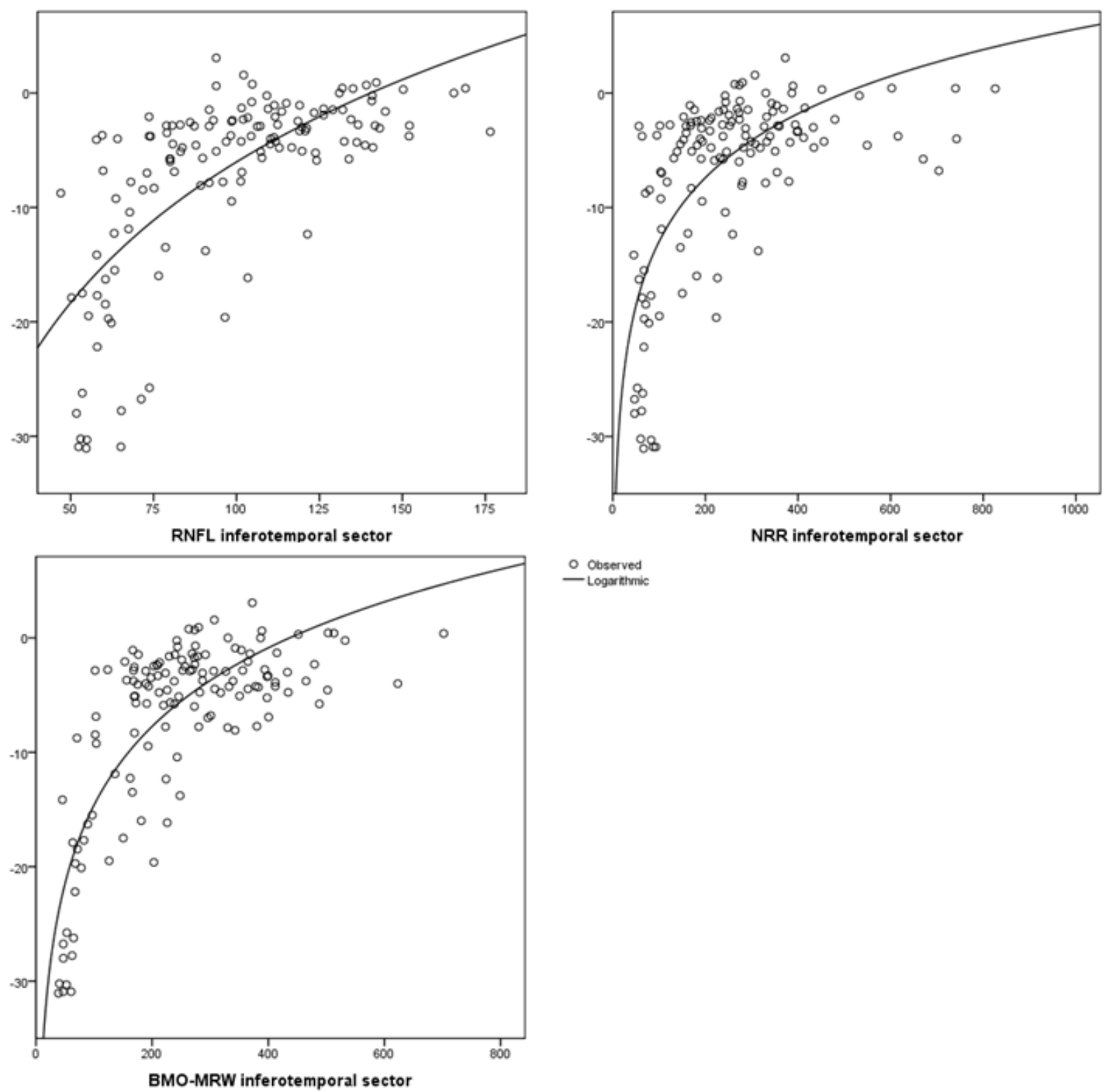

- Observed

Figure 3. Structure-function relationships. Scatter plots showing the association between visual field sensitivity $(\mathrm{dB})$ and Cirrus optical coherence tomography retinal nerve fiber layer thickness in the inferotemporal sector (top left, $\mu \mathrm{m}$ ), neuroretinal rim thickness in the 
inferotemporal sector (top right, $\mu \mathrm{m}$ ), and Bruch membrane opening minimum rim width in the inferotemporal sector (bottom, $\mu \mathrm{m}$ ), with linear and logarithmic fits.

From the scatter plots showing the association between visual field sensitivity and anatomical parameters (Figure 3), it is interesting to note that in advanced glaucoma (low visual field sensitivity and reduced RNFL or neuroretinal rim thickness: left parts of the scatterplots), the relationship between neuroretinal rim thickness (measured either by the Cirrus software or the BMO-MRW) and retinal sensitivity seems to be much stronger than the relationship between RNFL thickness and visual field sensitivity is. By contrast, earlier in the disease (MD>-15dB: right part of the scatterplots), RNFL thickness seems to correlate with function better than the neuroretinal rim thickness does (measured either by the Cirrus software or the BMO-MRW).

Linear and logarithmic regression analyses were performed to evaluate the relationship between RNFL and BMO-MRW in the six matching areas. The results are displayed in Table 3. In four of the six sectors (temporal, nasal, superonasal and inferonasal), the correlations are rather weak. In these four sectors, the strengths of the linear and logarithmic regressions are not significantly different. In two of the six sectors (superotemporal and inferotemporal), the correlations are stronger. In these two sectors, logarithmic associations were significantly stronger than linear associations.

\begin{tabular}{|c|ccc|ccc|}
\hline $\begin{array}{c}\text { Peripapillary } \\
\text { sector }\end{array}$ & \multicolumn{2}{|c|}{$\begin{array}{c}\text { Linear regression } \\
\text { (dependent variable: BMO-MRW) }\end{array}$} & \multicolumn{3}{c|}{$\begin{array}{c}\text { Logarithmic regression } \\
\text { (dependent variable: } \mathrm{BMO}-\mathrm{MRW} \text { ) }\end{array}$} \\
& $\mathrm{r}^{2}$ & $p$ & $\mathrm{y}=\mathrm{a}^{*} \mathrm{x}+\mathrm{b}$ & $\mathrm{r}^{2}$ & $p$ & $\mathrm{y}=\mathrm{a} * \ln (\mathrm{x})+\mathrm{b}$ \\
\hline
\end{tabular}




\begin{tabular}{|l|ccc|ccc|}
\hline Temporal & 0.279 & 0.001 & $y=2.9 x-3.7$ & 0.273 & 0.001 & $\mathrm{y}=185 \ln (\mathrm{x})-582$ \\
Superotemporal & 0.486 & $<0.001$ & $y=2.2 x+1.75$ & 0.560 & $<0.001$ & $\mathrm{y}=170 \ln (\mathrm{x})-555$ \\
Superonasal & 0.216 & 0.003 & $y=2.1 x+56.5$ & 0.137 & 0.2 & $\mathrm{y}=80.5 \ln (\mathrm{x})-109$ \\
Nasal & 0.143 & 0.6 & $y=5.2 x-51.7$ & 0.139 & 0.7 & $\mathrm{y}=331 \ln (\mathrm{x})-1090$ \\
Inferonasal & 0.349 & $<0.001$ & $y=4.3 x-63.7$ & 0.335 & $<0.001$ & $\mathrm{y}=354 \ln (\mathrm{x})-1261$ \\
Inferotemporal & 0.497 & $<0.001$ & $y=3.1 x-54.1$ & 0.588 & $<0.001$ & $\mathrm{y}=296 \ln (\mathrm{x})-1094$ \\
\hline
\end{tabular}

Table 3. Relationships between RNFL and NRR thicknesses.

\section{Diagnostic performance}

Table 4 shows the capability of Cirrus OCT parameters to discriminate glaucomatous or suspected glaucomatous eyes from healthy eyes, with sensitivities at $80 \%$ and $95 \%$ specificity. For RNFL-derived parameters, the largest AUROCs were seen for average RNFL in eyes with glaucoma and suspected glaucoma $(0.922$ [95\% confidence interval $0.881,0.963]$ and $0.863[0.769,0.957]$, respectively). For GCA-derived parameters, the largest AUROCs were seen for the GCA inferotemporal sector in eyes with glaucoma and suspected glaucoma $(0.901[0.836,0.965]$ and $0.769[0.657,0.880]$, respectively). For ONH-derived parameters, the largest AUROCs were seen for rim area in eyes with glaucoma and suspected glaucoma $(0.926[0.875,0.977]$ and 0.853 [0.759,0.947], respectively). For NRR-derived parameters, the largest AUROCs were seen for the inferotemporal sector in eyes with glaucoma and suspected glaucoma $(0.910[0.855,0.965]$ and $0.842[0.742,0.942]$, respectively). For BMOMRW-derived parameters, the largest AUROCs were seen for inferotemporal sector rim area in eyes with glaucoma and suspected glaucoma $(0.917$ [0.856,0.978] and $0.851[0.759,0.943]$, respectively). 


\begin{tabular}{|c|c|c|c|}
\hline Structure & Parameter & Glaucoma vs. healthy & Suspected vs. healthy \\
\hline RNFL & $\begin{array}{l}\text { Average } \\
\text { Temporal } \\
\text { Superior } \\
\text { Nasal } \\
\text { Inferior }\end{array}$ & $\begin{array}{c}.922[0.881,0.963] \\
91 \% ; 45 \% \\
.792[0.743,0.841] \\
78 \% ; 24 \% \\
.909[0.854,0.963] \\
70 \% ; 32 \% \\
.712[0.614,0.810] \\
76 \% ; 36 \% \\
.910[0.855,0.965] \\
88 \% ; 40 \%\end{array}$ & $\begin{array}{c}.863[0.769,0.957] \\
76 \% ; 66 \% \\
.732[0.612,0.851] \\
52 \% ; 44 \% \\
.785[0.671,0.899] \\
48 \% ; 42 \% \\
.649[0.509,0.788] \\
46 \% ; 40 \% \\
.850[0.754,0.946] \\
60 \% ; 68 \%\end{array}$ \\
\hline GCA & $\begin{array}{l}\text { Average } \\
\text { Minimum } \\
\text { Best of the six sectors } \\
\text { (GCA } \\
\text { inferotemporal) }\end{array}$ & $\begin{array}{c}.884[0.809,0.958] \\
85 \% ; 34 \% \\
.857[0.775,0.939] \\
78 \% ; 28 \% \\
.901[0.836,0.965] \\
84 \% ; 30 \%\end{array}$ & $\begin{array}{c}.716[0.596,0.835] \\
64 \% ; 4 \% \\
.706[0.588,0.824] \\
66 \% ; 12 \% \\
.769[0.657,0.880] \\
68 \% ; 4 \%\end{array}$ \\
\hline $\mathrm{ONH}$ & $\begin{array}{l}\text { Rim area } \\
\text { Disc area } \\
\text { Average c/d ratio } \\
\text { Vertical c/d ratio } \\
\text { Cup volume }\end{array}$ & $\begin{array}{c}.926[0.875,0.977] \\
88 \% ; 62 \% \\
.551[0.433,0.669] \\
32 \% ; 8 \% \\
.855[0.780,0.929] \\
84 \% ; 60 \% \\
.876[0.811,0.941] \\
76 \% ; 54 \% \\
.793[0.700,0.885] \\
74 \% ; 46 \%\end{array}$ & $\begin{array}{c}.853[0.759,0.947] \\
71 \% ; 42 \% \\
.572[0.435,0.709] \\
36 \% ; 4 \% \\
.738[0.638,0.838] \\
66 \% ; 30 \% \\
.761[0.643,0.878] \\
68 \% ; 32 \% \\
.689[0.565,0.812] \\
54 \% ; 18 \%\end{array}$ \\
\hline NRR & $\begin{array}{l}\text { Average } \\
\text { Best of the six sectors } \\
\text { (inferotemporal) }\end{array}$ & $\begin{array}{c}.878[0.805,0.950] \\
75 \% ; 6 \% \\
.910[0.855,0.965] \\
81 \% ; 5 \%\end{array}$ & $\begin{array}{c}.761[0.663,0.859] \\
41 \% ; 6 \% \\
.842[0.742,0.942] \\
46 \% ; 4 \%\end{array}$ \\
\hline
\end{tabular}




\begin{tabular}{|l|l|c|c|}
\hline BMO- & Average & $.906[0.839,0.972]$ & $.816[0.690,0.941]$ \\
MRW & & $80 \% ; 54 \%$ & $62 \% ; 16 \%$ \\
& Best of the six sectors & $.917[0.856,0.978]$ & $.851[0.759,0.943]$ \\
& (inferotemporal) & $80 \% ; 60 \%$ & $68 \% ; 18 \%$ \\
\hline
\end{tabular}

Table 4. Diagnostic capability of Cirrus OCT parameters. Areas under the receiver operator characteristic curve of the Cirrus OCT parameters for discriminating glaucomatous or suspected glaucomatous eyes from healthy eyes, with sensitivities at specificities of $80 \%$ and 95\%. Entries in each cell: line 1, area under the receiver operator characteristic curve and $95 \%$ confidence interval; line 2 , sensitivity at specificity of $80 \%$ - sensitivity at specificity of $95 \%$.

Comparisons of the AUROCs of the best parameters from each structure analyzed to distinguish glaucomatous or suspected glaucomatous eyes from healthy eyes are displayed in Table 5. The AUROC for the best RNFL and ONH parameters (RNFL average and rim area) was significantly greater than the area for the best GCA and NRR parameters (GCA inferotemporal sector and inferotemporal NRR; $p<0.05)$, but not significantly greater than the area for the best BMO-MRW parameter (inferotemporal sector; $p>0.1$ ). The receiver operating curves of the best Cirrus RNFL, GCA and ONH parameters for distinguishing glaucomatous or suspected glaucomatous eyes from healthy eyes are shown in Figure 4.

\begin{tabular}{|l|l|l|l|l|l|}
\hline & $\begin{array}{l}\text { RNFL } \\
\text { average }\end{array}$ & $\begin{array}{l}\text { GCA } \\
\text { inferotemporal } \\
\text { sector }\end{array}$ & Rim area & $\begin{array}{l}\text { NRR } \\
\text { inferotemporal } \\
\text { sector }\end{array}$ & $\begin{array}{l}\text { BMO-MRW } \\
\text { inferotemporal }\end{array}$ \\
\hline RNFL average & NA & $\mathbf{0 . 0 2}$ & 0.62 & $\mathbf{0 . 0 4}$ & 0.18 \\
& & $\mathbf{0 . 0 1}$ & 0.30 & $\mathbf{0 . 0 4}$ & 0.11 \\
\hline GCA & $\mathbf{0 . 0 2}$ & NA & $\mathbf{0 . 0 3}$ & 0.18 & 0.12 \\
\hline
\end{tabular}




\begin{tabular}{|l|l|l|l|l|l|}
\hline $\begin{array}{l}\text { inferotemporal } \\
\text { sector }\end{array}$ & $\mathbf{0 . 0 1}$ & & $\mathbf{0 . 0 2}$ & 0.20 & 0.10 \\
\hline Rim area & 0.62 & $\mathbf{0 . 0 3}$ & NA & $\mathbf{0 . 0 4}$ & 0.35 \\
& 0.30 & $\mathbf{0 . 0 2}$ & $\mathbf{0 . 0 5}$ & 0.19 \\
\hline NRR & $\mathbf{0 . 0 4}$ & 0.18 & $\mathbf{0 . 0 4}$ & NA & 0.16 \\
inferotemporal & $\mathbf{0 . 0 4}$ & 0.20 & $\mathbf{0 . 0 5}$ & & 0.10 \\
sector & & 0.12 & 0.35 & 0.16 & NA \\
\hline BMO-MRW & 0.18 & 0.10 & 0.19 & 0.10 & \\
inferotemporal & 0.11 & & & & \\
\hline
\end{tabular}

Table 5. Comparisons of the AUROCs of the best parameters from each structure analyzed to distinguish glaucomatous (first line in each cell) or suspected glaucomatous (second line in each cell) eyes from healthy eyes.
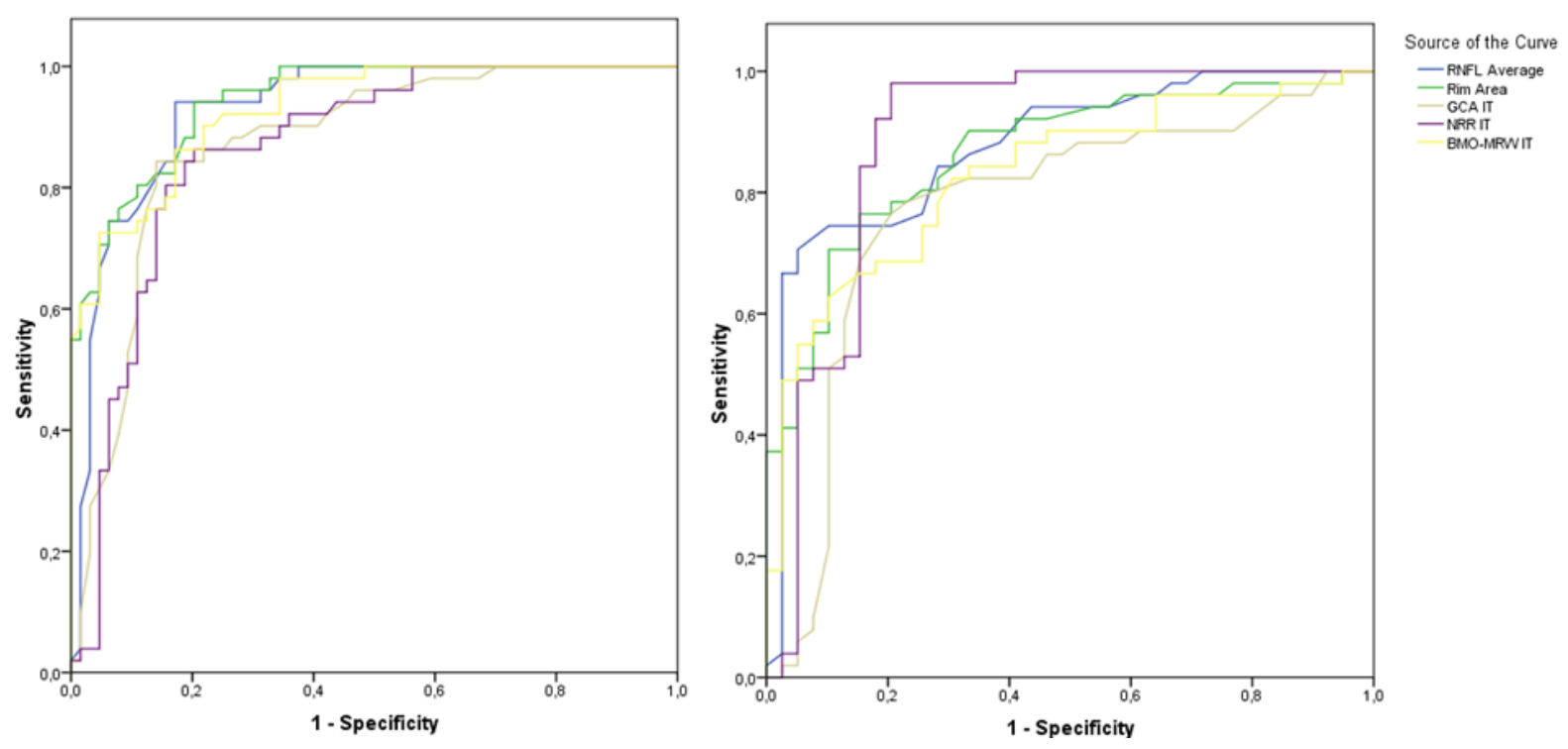

Figure 4. Diagnostic capability of Cirrus OCT. Receiver operating curves for the best parameters from each structure analyzed to distinguish glaucomatous (left) or suspected glaucomatous (right) eyes from healthy eyes

As the sensitivity at very high specificities could be of particular interest when evaluating the diagnostic abilities of such parameters, we have also evaluated the partial AUROCs at 95\% 
specificity cutoff levels. For RNFL-derived parameters, the largest partial AUROCs were seen for average RNFL in eyes with glaucoma and suspected glaucoma $(0.021 \pm .001$ and $0.014 \pm .002$, respectively). For GCA-derived parameters, the largest partial AUROCs were seen for average GCA in eyes with glaucoma and suspected glaucoma $(0.09 \pm .001$ and $0.06 \pm$ .001 , respectively). For ONH-derived parameters, the largest partial AUROCs were seen for rim area in eyes with glaucoma and suspected glaucoma $(0.026 \pm .002$ and $0.015 \pm .002$, respectively). For NRR-derived parameters, the largest partial AUROCs were seen for the inferotemporal sector in eyes with glaucoma and suspected glaucoma $(0.008 \pm .001$ and 0.004 \pm .001 , respectively). For BMO-MRW-derived parameters, the largest partial AUROCs were seen for inferotemporal sector rim area in eyes with glaucoma and suspected glaucoma $(0.024$ \pm .002 and $0.008 \pm .001$, respectively).

\section{DISCUSSION}

In this study, we found a significant regional relationship between visual field sensitivity and retinal nerve fiber layer thickness and optic nerve head measurements with spectral-domain OCT. Associations were frequently stronger with the new parameter Bruch membrane opening minimal rim width than other RNFL and ONH parameters, particularly in the later stages of the disease. The correlations $\left(\mathrm{r}^{2}\right)$ ranged from 0.07 to 0.60 with RNFL parameters, from 0.15 to 0.49 with Cirrus-based neuroretinal rim thickness and from 0.24 to 0.66 with BMO-MRW.

To the best of our knowledge, no previous study has evaluated and compared the regional relationship between RNFL and ONH structural measurements taken by OCT and visual field sensitivity. We found a stronger regional structure-function relationship with RNFL measurements than with neuroretinal rim thickness provided by the Cirrus internal specific software. We do not know how the thickness of the neuroretinal rim is calculated by the 
Cirrus specific software. This information is not clearly provided in the user manual or in the original publications made by the study group that validated the study of the optic nerve head using the Cirrus OCT. ${ }^{33-38}$ When studying the horizontal and vertical scan images that appear on the Cirrus printout, we can see that the thickness of the neuroretinal rim given by the software seems to be the distance between a black dot placed on the termination of the Bruch membrane and a red circle placed on the internal limiting membrane. The distance thus defined is generally not the shortest distance between the termination of the Bruch membrane and the inner limiting membrane, and is also generally not the horizontal distance between the Bruch membrane termination and the inner limiting membrane (i.e., the distance between $\mathrm{BMO}$ and internal limiting membrane along the BMO reference plane).

When we calculated the minimum distance between the Bruch membrane opening and the internal limiting membrane by exporting and analyzing the scan with image-processing software, we found a stronger relationship with visual field sensitivity than with the RNFL and the Cirrus-based neuroretinal rim thickness. This new anatomical parameter was recently proposed by Reis et al.and Chauhan et al. to take into account the variable orientation of rim tissue in the optic nerve head. Indeed, because the trajectory of the axons over the $\mathrm{ONH}$ depends on the orientation of border tissue, assessment of the non-minimal rim width (e.g., horizontal rim width) could be inaccurate. In eyes where the trajectory of the axons is more horizontal to the measurement plane, a wider rim estimate is obtained compared with eyes with the same number of axons but where the trajectory of the axons is more perpendicular. Even if we do not know the exact calculation strategy used by Cirrus software, obtaining stronger relationships with visual field sensitivity validates the pertinence of this calculation strategy, which should probably be used instead of those used by the commercially available software. From a clinical point of view, the relationship between functional measurements with standard achromatic perimetry and structural measurements is important, because 
glaucoma diagnosis and follow-up are often based on a combination of structural and functional assessments.

From the scatter plots showing the structure-function relationships, another important finding is that the neuroretinal rim thickness, either measured by the Cirrus software or using the BMO-MRW, seems to be much better correlated to the retinal sensitivity in advanced glaucoma than the RNFL is. The lack of association between RNFL thickness and visual field sensitivity in advanced glaucoma is well described and hypothesized to be due to a floor effect that occurs when there is almost no residual ganglion cell layer. ${ }^{37,38}$ For this reason, RNFL evaluation with OCT is usually less sensitive than visual field to track progression in advanced glaucoma. ${ }^{37}$ Neuroretinal rim thickness seems to be much better correlated to visual field sensitivity in advanced glaucoma. From the present data, it could be hypothesized that there is less of a floor effect with neuroretinal rim thickness, with changes that can be detected in eyes with advanced visual field loss. Further longitudinal studies should evaluate the value of the neuroretinal rim thickness assessment by OCT to monitor progression in advanced glaucoma. By contrast, in earlier stages of the disease, the RNFL thickness seems to be better correlated to the retinal sensitivity than the neuroretinal rim thickness is. This could be explained by RNFL tissue changes being easier to detect early in the disease, when there is still sufficient tissue left.

We also evaluated the discriminating capabilities of Cirrus RNFL, ONH, neuroretinal rim thickness and macular ganglion cell complex measurements. The best discrimination of glaucomatous and suspected glaucomatous eyes from healthy eyes were seen for rim area, ONH-derived parameters (AUROC 0.926 and 0.853, respectively); for average RNFL, RNFL-derived parameters (AUROC 0.922 and 0.863, respectively); for inferotemporal 
neuroretinal rim thickness, BMO-MRW-derived parameters (AUROC 0.917 and 0.851 , respectively); for inferotemporal neuroretinal rim thickness, Cirrus-derived parameters (AUROC 0.910 and 0.842, respectively), and for the GCA inferotemporal sector, GCAderived parameters (AUROC 0.901 and 0.769 , respectively).

A few previously published studies have evaluated and compared the capabilities of RNFL and $\mathrm{ONH}$ parameters measured with OCT to discriminate between glaucomatous and healthy eyes. Medeiros et al. used Stratus OCT and found no significant differences between the AUROC for the RNFL thickness parameters (inferior 0.91) and the ONH parameters (cup/disc ratio area, 0.88). ${ }^{22}$ Also using the Stratus, Leung et al. found that the best parameters for distinguishing early glaucoma from healthy eyes were rim volume (AUROC 0.966), cup/disc vertical ratio (AUROC 0.962), cup/disc area ratio (AUROC 0.960) and RNFL thickness (AUROC 0.957). ${ }^{23}$ Using a more recent OCT technique with RT-Vue SD-OCT, Rao et al. found inferior performance with ONH measurements compared with RNFL thickness parameters (best AUROC inferior rim area 0.812 and inferior RNFL 0.884, respectively). ${ }^{24}$ Using Cirrus OCT, Sung et al. found that RNFL average thickness was a better parameter for distinguishing advanced glaucoma from healthy eyes than rim area or cup/disc ratio or cup volume (AUC 0.957 versus 0.871 ) ${ }^{25}$ Using Cirrus OCT, Mwanza et al. found comparable diagnostic capabilities of ONH parameters compared to RNFL thickness (AUROC: vertical rim thickness 0.963 , RNFL at $7^{\prime} 0.957$, average RNFL 0.950 ). ${ }^{33}$

Differences in acquisition speed, scanning rate, spatial resolutions, together with different layer detection algorithms and analytical software, may lead to different retinal nerve fiber layer thickness and $\mathrm{ONH}$ measurements and could explain the differences between the different commercially available OCT machines. Methodological reasons such as differences in the number of subjects included, differences in the representation of the different stages of glaucoma or differences in ethnicity could explain the variable results obtained with the 
Cirrus OCT. For instance, Sung et al. included Asians, who could have anatomical differences in RNFL and ONH compared with Caucasians. ${ }^{25}$ With a very similar methodology and population to those used in our study, Mwanza et al. obtained comparable results to those of the present study. ${ }^{33}$

When analyzing the discriminating capabilities provided by the BMO-MRW and Cirrus for neuroretinal thickness measurements, we found a slightly but significantly better performance with the BMO-MRW parameters. It is interesting to note that we found a smaller difference than Chauhan et al. found when comparing the capabilities of the BMO-MRW and BMOHRW obtained with the Spectralis. ${ }^{27}$ This could be due to the fact that the Spectralis software used the optic disc plane as reference (horizontally defined by the opening of the Bruch membrane), whereas Cirrus OCT software measures the rim thickness as the RNFL turns to exit the optic nerve in a less horizontal manner. As the exact algorithm used by the Cirrus is not publicly available, caution should be exercised when assuming that Cirrus measurements are probably closer to the BMO-MRW. Similarly, these findings confirm that this new parameter should probably be used instead of those used by commercially available software.

In conclusion, the present study shows that measurements of the retinal nerve fiber layer thickness and optic nerve head with SD-OCT correlate well with retinal ganglion cell function as assessed using standard achromatic perimetry. The structure-function relationship was in general stronger with the new parameter Bruch membrane opening minimal rim width than the retinal nerve fiber layer parameters, and stronger with the retinal nerve fiber layer parameters than the other optic nerve head parameters. This new parameter could be integrated into the commercially available OCT software to improve glaucoma diagnosis and follow-up. 


\section{REFERENCES}

1. Weinreb RN, Khaw PT. Primary open-angle glaucoma. Lancet. 2004;363:1711-1720.

2. Quigley HA, Miller NR, George T. Clinical evaluation of nerve fiber layer atrophy as an indicator of glaucomatous optic nerve damage. Arch Ophthalmol. 1980;98:1564-1571.

3. Betz P, Camps F, Collignon-Brach J, Lavergne G, Weekers R. Biometric study of the disc cup in open-angle glaucoma. Graefes Arch ClinExpOphthalmol. 1982;218:70-74.

4. Huang D, Swanson EA, Lin CP, et al. Optical coherence tomography. Science. 1991;254:1178-1181.

5. Drexler W, Morgner U, Kärtner FX, et al. In vivo ultrahigh-resolution optical coherence tomography. Opt Lett. 1999;24:1221-1223.

6. Dreher AW, Bailey ED. Assessment of the retinal nerve fiber layer by scanning-laser polarimetry. SPIE. 1993;1877:266-271.

7. Weinreb RN, Shakiba S, Zangwill L. Scanning laser polarimetry to measure the nerve fiber layer of normal and glaucomatous eyes. Am J Ophthalmol. 1995;119:627-636.

8. Weinreb RN, Shakiba S, Sample PA, et al. Association between quantitative nerve fiber layer measurement and visual field loss in glaucoma. Am J Ophthalmol. 1995;120:732738.

9. Lan YW, Henson DB, Kwartz AJ. The correlation between optic nerve head topographic measurements, peripapillary nerve fibre layer thickness, and visual field indices in glaucoma. Br J Ophthalmol. 2003;87:1135-1141.

10. El Beltagi TA, Bowd C, Boden C, et al. Retinal nerve fiber layer thickness measured with optical coherence tomography is related to visual function in glaucomatous eyes. Ophthalmology. 2003;110:2185-2191.

11. Reus NJ, Lemij HG. The relationship between standard automated perimetry and GDx VCC measurements. Invest Ophthalmol Vis Sci. 2004;45:840-845.

12. Leung CK, Chong KK, Chan WM, et al. Comparative study of retinal nerve fiber layer measurement by StratusOCT and GDx VCC, II: structure/function regression analysis in glaucoma. Invest Ophthalmol Vis Sci. 2005;46:3702-3711.

13. Reus NJ, Lemij HG. Relationships between standard automated perimetry, HRT confocal scanning laser ophthalmoscopy, and GDx VCC scanning laser polarimetry. Invest Ophthalmol Vis Sci. 2005;46:4182-4188.

14. Hoffmann EM, Medeiros FA, Sample PA, et al. Relationship between patterns of visual field loss and retinal nerve fiber layer thickness measurements. Am J Ophthalmol. 2006;141:463-471. 
15. Bowd C, Zangwill LM, Medeiros FA, et al. Structure-function relationships using confocal scanning laser ophthalmoscopy, optical coherence tomography, and scanning laser polarimetry. Invest Ophthalmol Vis Sci. 2006;47:2889-2895.

16. Kanamori A, Naka M, Nagai-Kusuhara A, Yamada Y, Nakamura M, Negi A. Regional relationship between retinal nerve fiber layer thickness and corresponding visual field sensitivity in glaucomatous eyes. Arch Ophthalmol. 2008;126:1500-1506.

17. Mai TA, Reus NJ, Lemij HG. Structure-function relationship is stronger with enhanced corneal compensation than with variable corneal compensation in scanning laser polarimetry. Invest Ophthalmol Vis Sci. 2007;48:1651-1658.

18. Bowd C, Tavares IM, Medeiros FA, Zangwill LM, Sample PA, Weinreb RN. Retinal nerve fiber layer thickness and visual sensitivity using scanning laser polarimetry with variable and enhanced corneal compensation. Ophthalmology. 2007;114:1259-1265.

19. Choi J, Kim KH, Lee $\mathrm{CH}$, et al. Relationship between retinal nerve fibre layer measurements and retinal sensitivity by scanning laser polarimetry with variable and enhanced corneal compensation. Br J Ophthalmol. 2008;92:906-911.

20. Horn FK, Mardin CY, Laemmer R, et al. Correlation between local glaucomatous visual field defects and loss of nerve fiber layer thickness measured with polarimetry and spectral domain OCT. Invest Ophthalmol Vis Sci. 2009;50:1971-1977.

21. Aptel F, Sayous R, Fortoul V, Beccat S, Denis P. Structure-function relationships using spectral-domain optical coherence tomography: comparison with scanning laser polarimetry. Am J Ophthalmol. 2010;150:825-833.

22. Medeiros FA, Zangwill LM, Alencar LM, et al. Detection of glaucoma progression with stratus OCT retinal nerve fiber layer, optic nerve head, and macular thickness measurements. Invest Ophthalmol Vis Sci. 2009 Dec;50:5741-5748.

23. Leung CK, Chan WM, Hui YL, et al. Analysis of retinal nerve fiber layer and optic nerve head in glaucoma with different reference plane offsets, using optical coherence tomography. Invest Ophthalmol Vis Sci. 2005 Mar;46:891-899.

24. Rao HL, Zangwill LM, Weinreb RN, Sample PA, Alencar LM, Medeiros FA. Comparison of different spectral domain optical coherence tomography scanning areas for glaucoma diagnosis. Ophthalmology. 2010 Sep;117:1692-1699,

25. Sung K, Na J, Lee Y. Glaucoma diagnostic capabilities of optic nerve head parameters as determined by Cirrus HD Optical Coherence Tomography. J Glaucoma. 2012;21:498-504. 
26. Reis AS, O'Leary N, Yang H, et al. Influence of clinically invisible, but optical coherence tomography detected, optic disc margin anatomy on neuroretinal rim evaluation. Invest Ophthalmol Vis Sci. 2012 Apr 18;53:1852-1860.

27. Chauhan BC, O'Leary N, Almobarak FA, et al. Enhanced Detection of Open-angle Glaucoma with an Anatomically Accurate Optical Coherence Tomography-Derived Neuroretinal Rim Parameter. Ophthalmology. 2013 Mar;120:535-543.

28. Garway-Heath DF, Poinoosawmy D, Fitzke FW, Hitchings RA. Mapping the visual field to the optic disc in normal tension glaucoma eyes. Ophthalmology. 2000;107:1809-1815. 29. Garway-Heath DF, Holder GE, Fitzke FW, Hitchings RA. Relationship between electrophysiological, psychophysical, and anatomical measurements in glaucoma. Invest Ophthalmol Vis Sci. 2002;43:2213-2220.

30. Hood DC, Anderson SC, Wall M, Kardon RH. Structure versus function in glaucoma: an application of a linear model. Invest Ophthalmol Vis Sci. 2007;48:3662-3668.

31. Leung CK, Lam S, Weinreb RN, et al. Retinal nerve fiber layer imaging with spectraldomain optical coherence tomography: analysis of the retinal nerve fiber layer map for glaucoma detection. Ophthalmology. 2010;117:1684-1691.

32. DeLong ER, DeLong DM, Clarke-Pearson DL. Comparing the areas under two or more correlated receiver operating characteristic curves: a nonparametric approach. Biometrics. 1988;44:837-845.

33. Mwanza JC, Oakley JD, Budenz DL, Anderson DR; Cirrus Optical Coherence Tomography Normative Database Study Group. Ability of cirrus HD-OCT optic nerve head parameters to discriminate normal from glaucomatous eyes. Ophthalmology. 2011 Feb;118:241-248

34. Mwanza JC, Durbin MK, Budenz DL; Cirrus OCT Normative Database Study Group. Interocular symmetry in peripapillary retinal nerve fiber layer thickness measured with the Cirrus HD-OCT in healthy eyes. Am J Ophthalmol. 2011 Mar;151:514-521.

35. Mwanza JC, Durbin MK, Budenz DL, et al. Cirrus OCT Normative Database Study Group. Profile and predictors of normal ganglion cell-inner plexiform layer thickness measured with frequency-domain optical coherence tomography. Invest Ophthalmol Vis Sci. 2011 Oct 4;52:7872-7879.

36. Knight OJ, Girkin CA, Budenz DL, Durbin MK, Feuer WJ; Cirrus OCT Normative Database Study Group. Effect of race, age, and axial length on optic nerve head parameters and retinal nerve fiber layer thickness measured by Cirrus HD-OCT. Arch Ophthalmol 2012 Mar;130:312-318. 
37. Leung CK, Cheung CY, Weinreb RN, et al. Evaluation of retinal nerve fiber layer progression in glaucoma: A study on optical coherence tomography guided progression analysis. Invest Ophthalmol Vis Sci. 2010 Jan;51:217-222.

38. Wollstein G, Kagemann L, Bilonick RA, et al. Retinal nerve fibre layer and visual function loss in glaucoma: the tipping point. Br J Ophthalmol. 2012 Jan;96:47-52. 

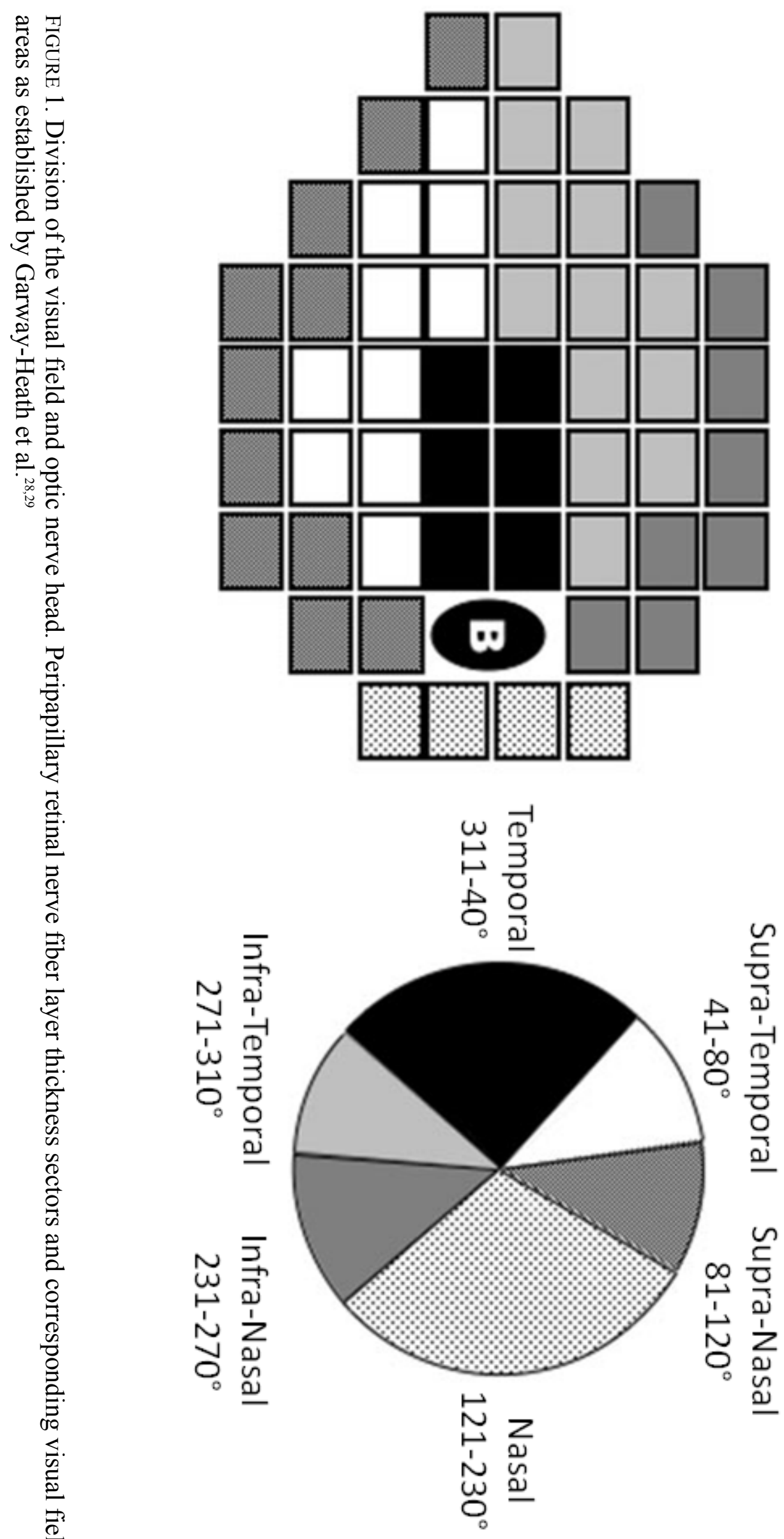


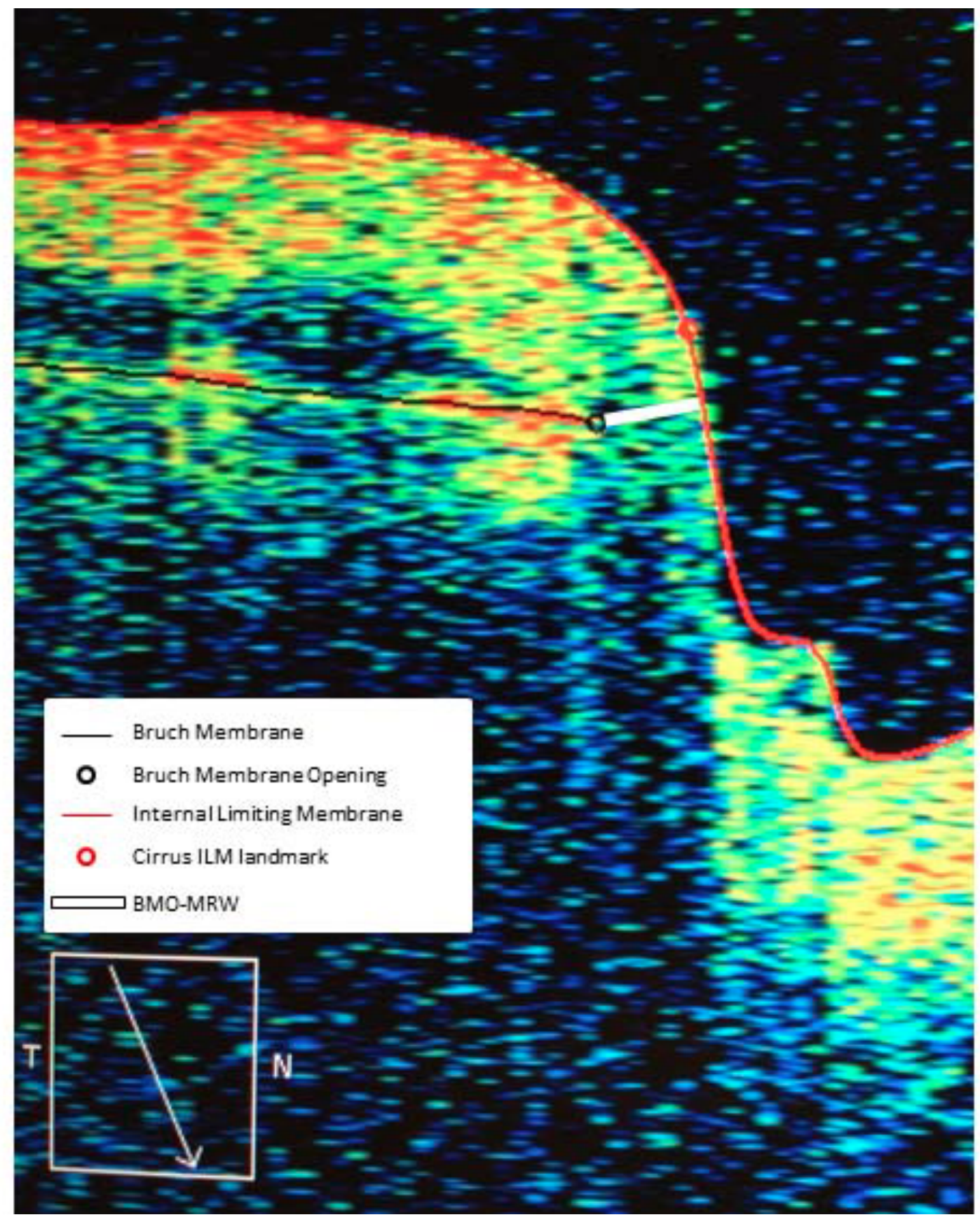

FIGURE 2. Example of cross-sectional optic nerve head image in the inferonasal sector. Bruch membrane, Bruch membrane opening, internal limiting membrane, and internal limiting membrane landmark are automatically defined by the Cirrus internal-specific software. Note the difference between the BMO-MRW distance and the neuroretinal rim thickness provided by the Cirrus software (distance between black and red dots). ILM, internal limiting membrane. 

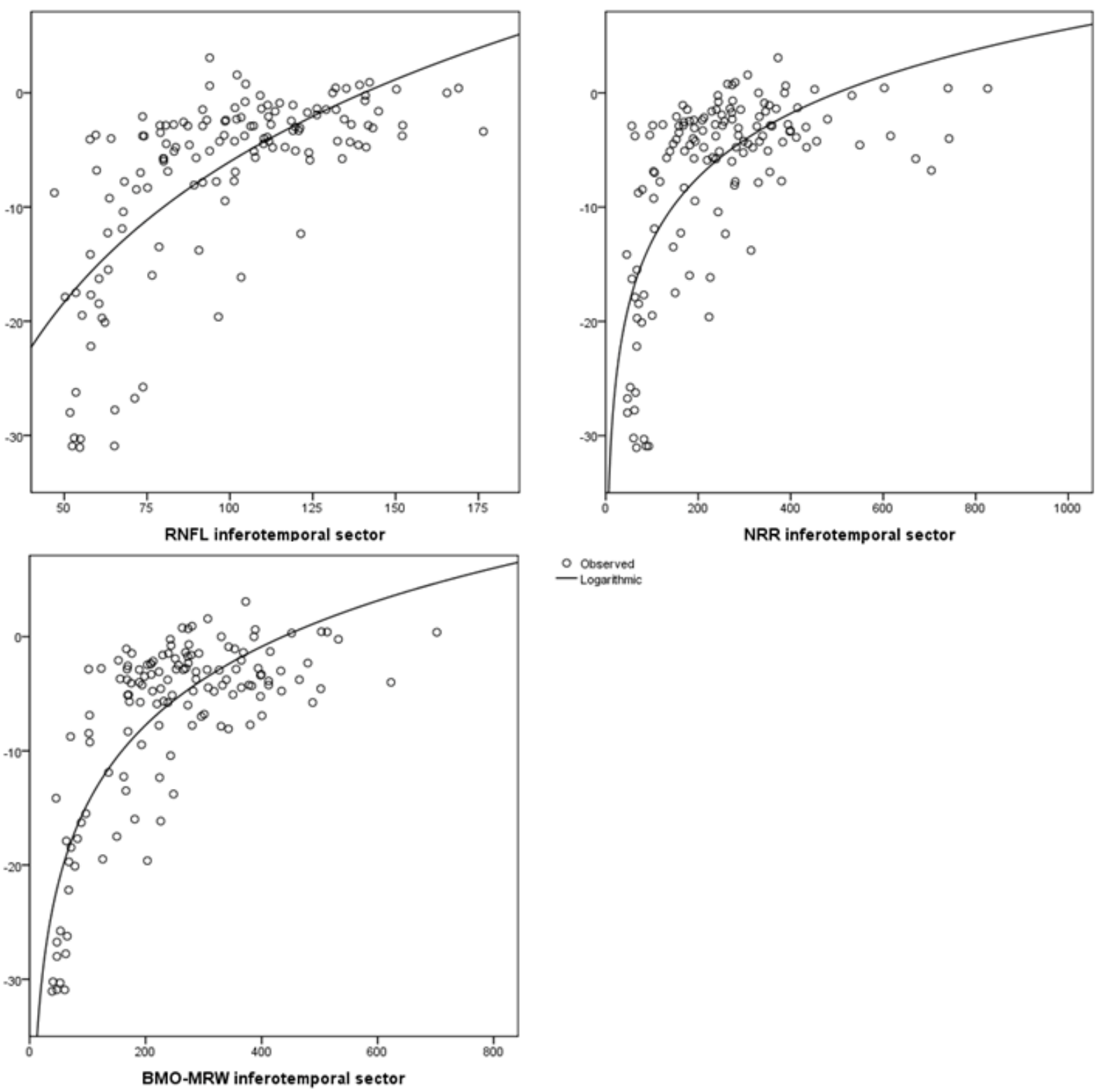

FIgURE 3. Structure-function relationships. Scatter plots showing the association between visual field sensitivity $(\mathrm{dB})$ and Cirrus optical coherence tomography retinal nerve fiber layer thickness in the inferotemporal sector (top left, $\mu \mathrm{m}$ ), neuroretinal rim thickness in the inferotemporal sector (top right, $\mu \mathrm{m}$ ), and Bruch membrane opening minimum rim width in the inferotemporal sector (bottom, $\mu m$ ), with logarithmic fit. 


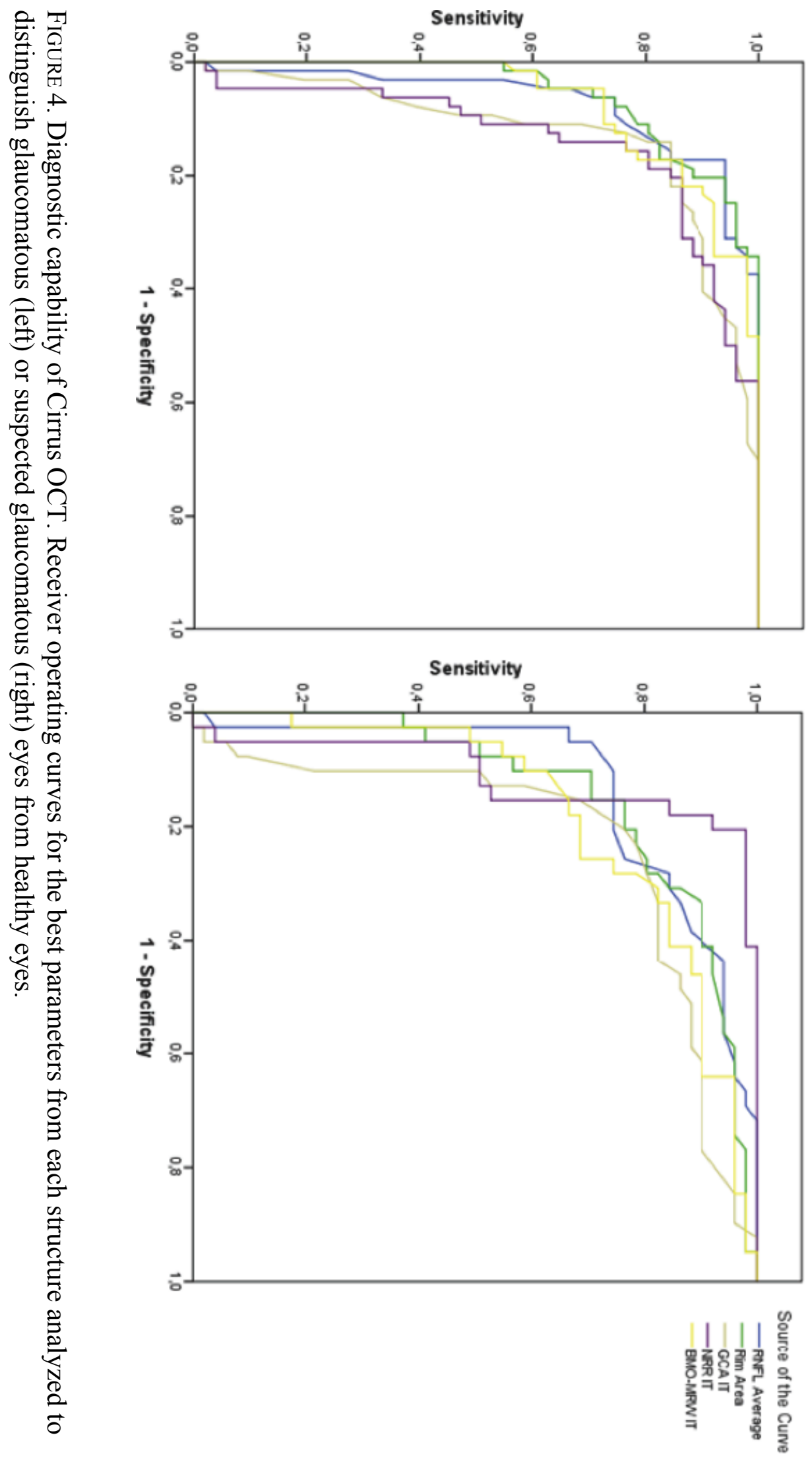




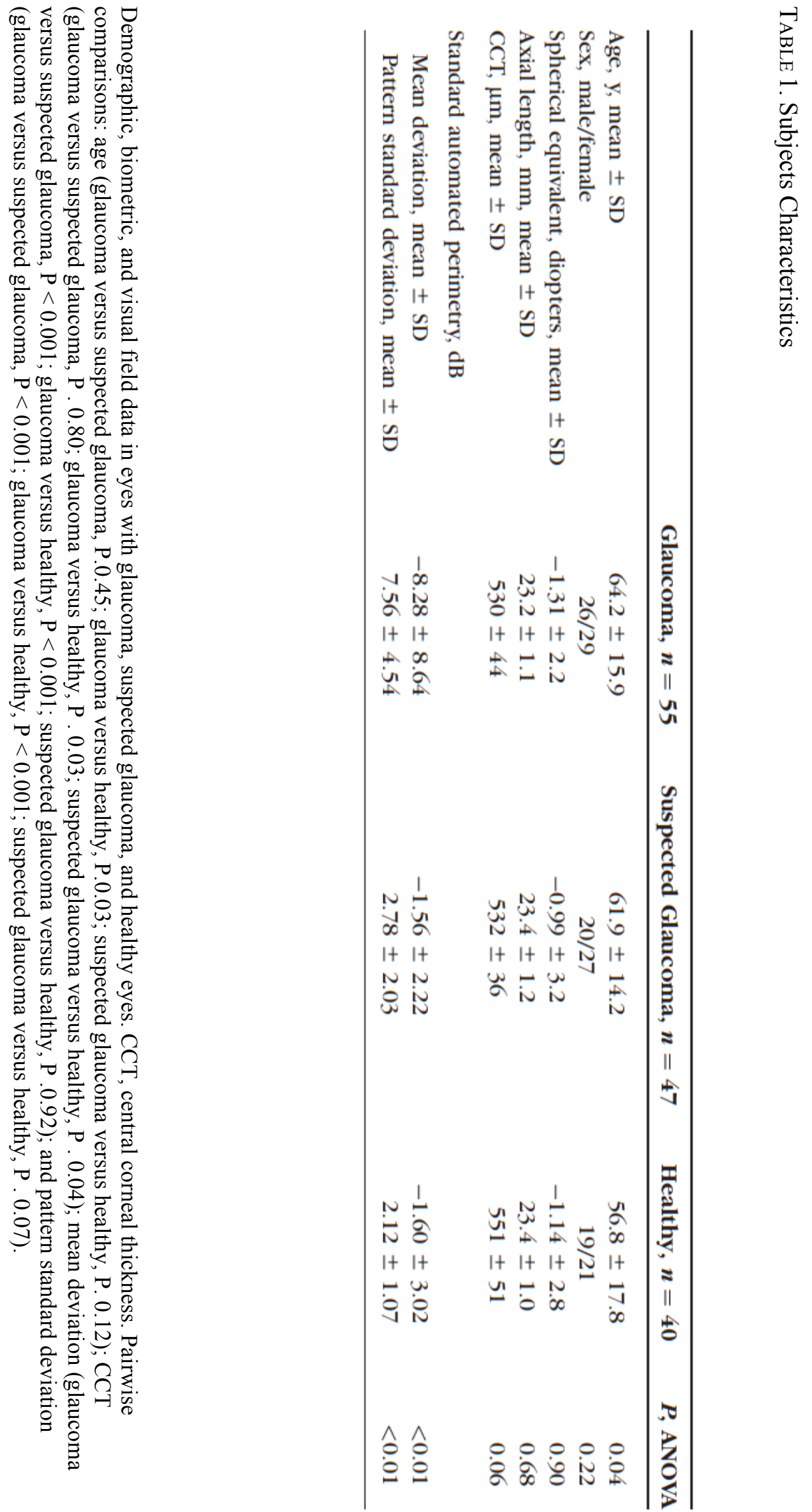




\section{Logarithmic Regression}

\begin{tabular}{llll} 
Peripapillary Sector & $r^{2}$ & $P$ & $y=a^{*} \ln (x)+b$ \\
\hline
\end{tabular}

RNFL

$\begin{array}{lrrr}\text { Temporal } & 0.093 & 0.003 & y=9.9 \ln (x)-19.3 \\ \text { Superotemporal } & 0.495 & <0.001 & y=15.8 \ln (x)-24.6 \\ \text { Superonasal } & 0.274 & <0.001 & y=11.2 \ln (x)-4.6 \\ \text { Nasal } & 0.065 & 0.005 & y=9.51 \ln (x)-25.8 \\ \text { Inferonasal } & 0.263 & <0.001 & y=15.4 \ln (x)-67.1 \\ \text { Inferotemporal } & 0.598 & <0.001 & y=17.2 \ln (x)-77.5\end{array}$

NRR

$\begin{array}{lccl}\text { Temporal } & 0.401 & <0.001 & y=8.70 \ln (x)-17.3 \\ \text { Superotemporal } & 0.457 & <0.001 & y=8.58 \ln (x)-33.7 \\ \text { Superonasal } & 0.328 & <0.001 & y=9.57 \ln (x)-25.6 \\ \text { Nasal } & 0.154 & 0.05 & y=7.67 \ln (x)-3.44 \\ \text { Inferonasal } & 0.259 & <0.001 & y=9.77 \ln (x)-26.4 \\ \text { Inferotemporal } & 0.494 & <0.001 & y=8.91 \ln (x)-41.1\end{array}$

\section{BMO-MRW}

$\begin{array}{llll}\text { Temporal } & 0.457 & <0.001 & y=8.67 \ln (x)-8.50 \\ \text { Superotemporal } & 0.604 & <0.001 & y=8.88 \ln (x)-19.7 \\ \text { Superonasal } & 0.523 & <0.001 & y=8.75 \ln (x)-21.8 \\ \text { Nasal } & 0.241 & <0.001 & y=6.41 \ln (x)-5.44 \\ \text { Inferonasal } & 0.460 & <0.001 & y=8.85 \ln (x)-23.6 \\ \text { Inferotemporal } & 0.658 & <0.001 & y=10.1 \ln (x)-42.3\end{array}$

Logarithmic regression between Cirrus optical coherence tomography-measured retinal nerve fiber layer thickness, neuroretinal rim thickness, and Bruch membrane opening minimum rim width in the six peripapillary sectors and visual field sensitivity $(\mathrm{dB})$ in the six corresponding areas. 


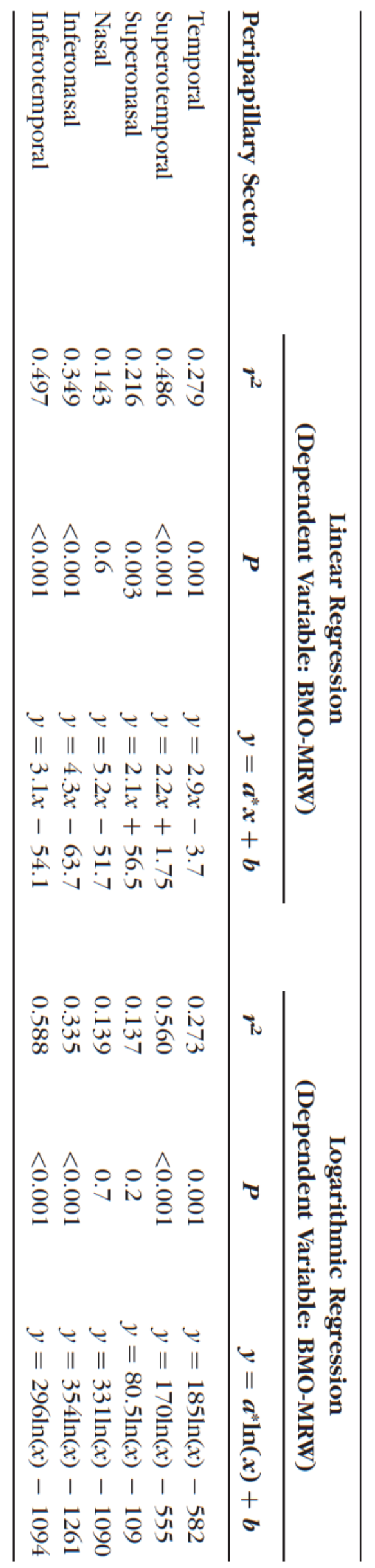

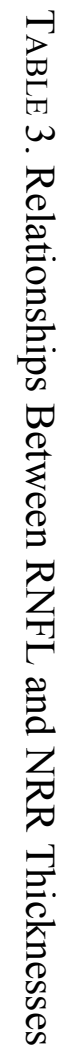


TABLE 4. Diagnostic Capability of Cirrus OCT Parameters

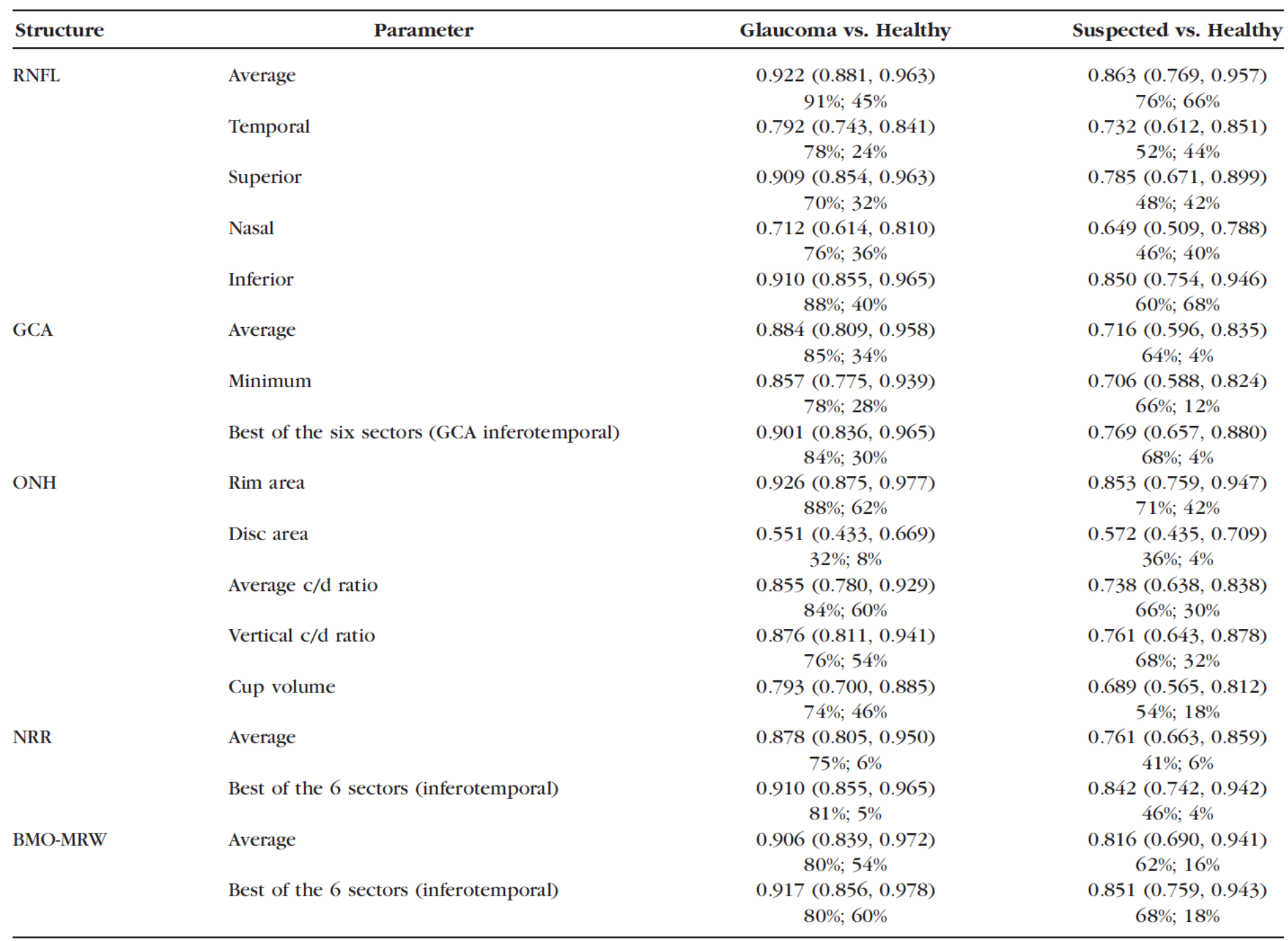

Areas under the receiver operator characteristic curve of the Cirrus OCT parameters for discriminating glaucomatous or suspected glaucomatous eyes from healthy eyes, with sensitivities at specificities of $80 \%$ and $95 \%$. Entries in each cell: line 1, area under the receiver operator characteristic curve and $95 \%$ confidence interval; line 2 , sensitivity at specificity of $80 \%$ - sensitivity at specificity of $95 \%$. 


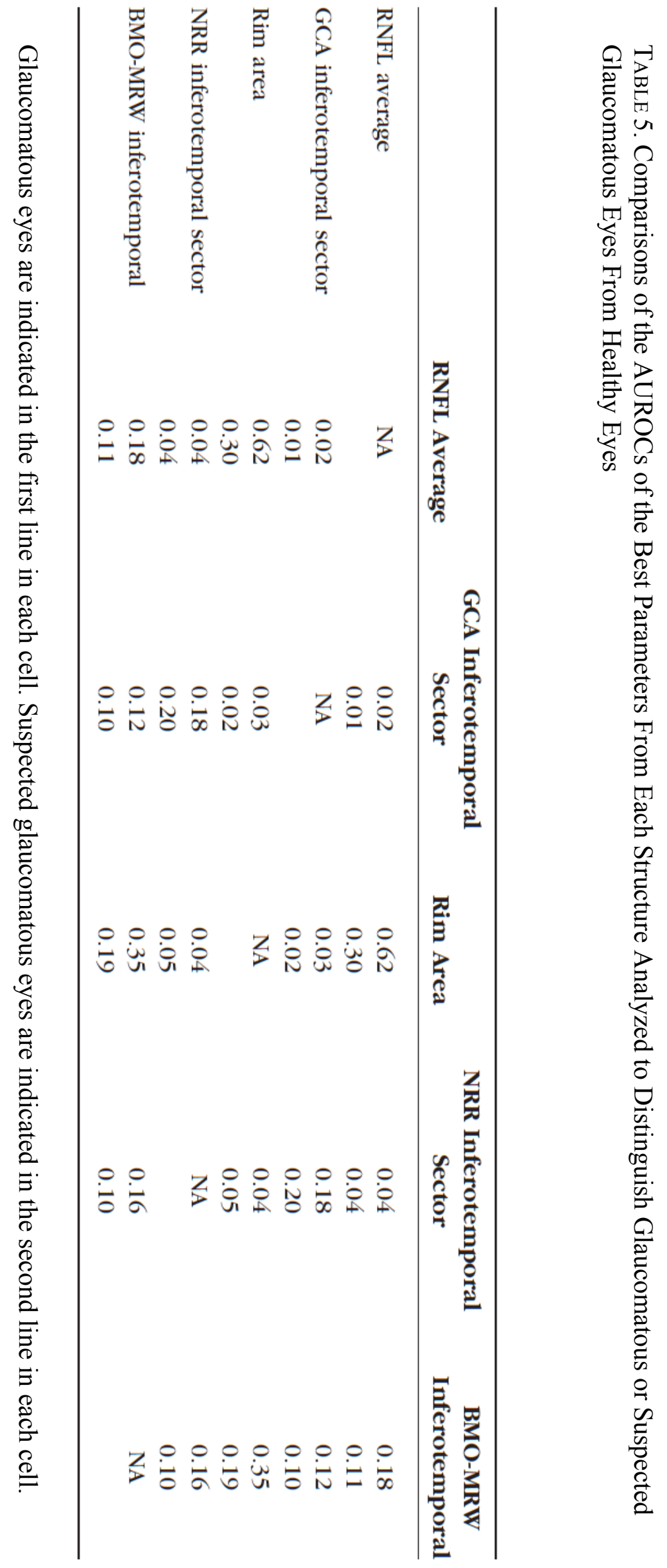




\section{TITRE : Relation avec les atteintes du champ visuel et aptitude diagnostique des mesures de la couche des fibres optiques et de la tête du nerf optique en OCT spectral- domain}

Objectifs : Evaluer les relations entre l'épaisseur de la couche des fibres optiques péripapillaires (RNFL) et de l'anneau neuro-rétinien (NRR) mesurées par tomographie par cohérence optique spectral domain (Cirrus SD-OCT), et la sensibilité rétinienne estimée en périmétrie automatisée. Comparer l'aptitude diagnostique des mesures de la couche des fibres optiques (RNFL), de la tête du nerf optique $(\mathrm{ONH})$ et du complexe ganglionnaire maculaire (MGCC) en OCT Cirrus.

Matériel et méthodes : 142 sujets ( 55 glaucomateux, 47 suspects et 40 cas témoins) ont bénéficiés de façon prospective d'une mesure de l'épaisseur RNFL, de la topographie de la tête du nerf optique (ONH et NRR) et de l'épaisseur MGCC par Cirrus OCT, et d'un relevé du champ visuel par périmétrie automatisée Humphrey 24.2 SITA Standard. L'épaisseur de la couche des fibres optiques (RNFL) de 12 secteurs péripapillaires de $30^{\circ}$, l'épaisseur de l'anneau neuro-rétinien (NRR) fournie par l'OCT Cirrus et la distance minimale entre la terminaison de la membrane de Bruch et la limitante interne (BMO-MRW), mesurées à partir de 36 scans espacés de $10^{\circ}$ de l'anneau neuro-rétinien, ont été collectées. Les relations entre les paramètres structuraux et la sensibilité rétinienne ont été évaluées globalement et pour 6 secteurs circum-papillaires (classification de Garway-Heath: inféro-nasal, inféro-temporal, temporal, supéro-temporal, supéro-nasal et nasal) par régression logarithmique. Pour l'ensemble des paramètres d'analyse (RNFL, ONH, MGCC), les courbes ROC (Receiver Operating Characteristics) ont permis de comparer l'aptitude à différencier les yeux glaucomateux ou suspects des yeux sains.

Résultats : L'association $\left(r^{2}\right)$ entre la sensibilité rétinienne et les épaisseurs RNFL, de l'anneau neurorétinien mesurés par l'OCT Cirrus (NRR) et la distance minimale entre la membrane de Bruch et la limitante interne (BMO-MRW) variait respectivement de 0,07 à 0,60 , de 0,15 à 0,49 et de 0,24 à 0,66 . La relation structure-fonction était plus forte pour la distance BMO-MRW que pour l'épaisseur NRR mesurée par l'OCT Cirrus.

L'aire sous la courbe ROC la plus large correspondait à l'aire de l'anneau neurorétinien (NRR) $(0,926-I C 95 \% 0,875,0,977)$ pour les yeux glaucomateux, et à l'épaisseur RNFL moyenne $(0,863$ - IC95\% 0,769, 0,957) pour les yeux suspects.

Discussion : La relation topographique est plus forte avec la distance BMO-MRW qu'avec les mesures RNFL ou de l'anneau neurorétinien mesurées par l'OCT Cirrus. La sensibilité rétinienne est mieux corrélée avec la mesure RNFL dans les glaucomes débutants alors que la corrélation semble plus forte avec la mesure de l'anneau neurorétinien dans les glaucomes avancés.

Conclusions: La relation structure-fonction était significativement plus forte avec le nouveau paramètre BMO-MRW qu'avec l'épaisseur de la couche des fibres optiques (RNFL) ou l'épaisseur de l'anneau neuro-rétinien (NRR) fournies par l'OCT Cirrus. Les meilleurs paramètres pour distinguer les patients glaucomateux et suspects des yeux sains étaient l'aire de l'anneau neurorétinien (NRR) et l'épaisseur RNFL moyenne.

MOTS CLÉS : glaucome, champ visuel, relation structure-fonction, tomographie par cohérence optique. 
TITRE : Relation avec les atteintes du champ visuel et aptitude diagnostique des mesures de la couche des fibres optiques et de la tête du nerf optique en OCT spectraldomain

Objectifs : Evaluer les relations entre l'épaisseur de la couche des fibres optiques péripapillaires (RNFL) et de l'anneau neuro-rétinien (NRR) mesurées par tomographie par cohérence optique spectral domain (Cirrus SD-OCT), et la sensibilité rétinienne estimée en périmétrie automatisée. Comparer l'aptitude diagnostique des mesures de la couche des fibres optiques (RNFL), de la tête du nerf optique (ONH) et du complexe ganglionnaire maculaire (MGCC) en OCT Cirrus.

Matériel et méthodes : 142 sujets (55 glaucomateux, 47 suspects et 40 cas témoins) ont bénéficiés de façon prospective d'une mesure de l'épaisseur RNFL, de la topographie de la tête du nerf optique (ONH et NRR) et de l'épaisseur MGCC par Cirrus OCT, et d'un relevé du champ visuel par périmétrie automatisée Humphrey 24.2 SITA Standard. L'épaisseur de la couche des fibres optiques (RNFL) de 12 secteurs péripapillaires de $30^{\circ}$, l'épaisseur de l'anneau neuro-rétinien (NRR) fournie par l'OCT Cirrus et la distance minimale entre la terminaison de la membrane de Bruch et la limitante interne (BMO-MRW), mesurées à partir de 36 scans espacés de $10^{\circ}$ de l'anneau neuro-rétinien, ont été collectées. Les relations entre les paramètres structuraux et la sensibilité rétinienne ont été évaluées globalement et pour 6 secteurs circum-papillaires (classification de Garway-Heath: inféro-nasal, inféro-temporal, temporal, supéro-temporal, supéro-nasal et nasal) par régression logarithmique. Pour l'ensemble des paramètres d'analyse (RNFL, ONH, MGCC), les courbes ROC (Receiver Operating Characteristics) ont permis de comparer l'aptitude à différencier les yeux glaucomateux ou suspects des yeux sains.

Résultats : L'association $\left(r^{2}\right)$ entre la sensibilité rétinienne et les épaisseurs RNFL, de l'anneau neurorétinien mesurés par l'OCT Cirrus (NRR) et la distance minimale entre la membrane de Bruch et la limitante interne (BMO-MRW) variait respectivement de 0,07 à 0,60 , de 0,15 à 0,49 et de 0,24 à 0,66 . La relation structure-fonction était plus forte pour la distance BMO-MRW que pour l'épaisseur NRR mesurée par l'OCT Cirrus.

L'aire sous la courbe ROC la plus large correspondait à l'aire de l'anneau neurorétinien (NRR) $(0,926-I C 95 \% 0,875,0,977)$ pour les yeux glaucomateux, et à l'épaisseur RNFL moyenne $(0,863-$ IC95\% 0,769, 0,957) pour les yeux suspects.

Discussion : La relation topographique est plus forte avec la distance BMO-MRW qu'avec les mesures RNFL ou de l'anneau neurorétinien mesurées par l'OCT Cirrus. La sensibilité rétinienne est mieux corrélée avec la mesure RNFL dans les glaucomes débutants alors que la corrélation semble plus forte avec la mesure de l'anneau neurorétinien dans les glaucomes avancés.

Conclusions: La relation structure-fonction était significativement plus forte avec le nouveau paramètre BMO-MRW qu'avec l'épaisseur de la couche des fibres optiques (RNFL) ou l'épaisseur de l'anneau neuro-rétinien (NRR) fournies par l'OCT Cirrus. Les meilleurs paramètres pour distinguer les patients glaucomateux et suspects des yeux sains étaient l'aire de l'anneau neurorétinien (NRR) et l'épaisseur RNFL moyenne.

VU ET PERMIS D'IMPRIMER

\section{LE DOYEN}

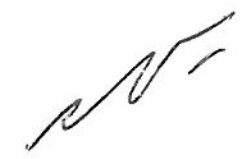

J.P. ROMANET
Grenoble, le 10 Février 2015

LE PRESIDENT DE LA THESE

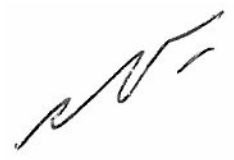

Professeur Jean Paul Romanet 


\section{TITRE : Relation avec les atteintes du champ visuel et aptitude diagnostique des mesures de la couche des fibres optiques et de la tête du nerf optique en OCT spectral- domain}

Objectifs : Evaluer les relations entre l'épaisseur de la couche des fibres optiques péripapillaires (RNFL) et de l'anneau neuro-rétinien (NRR) mesurées par tomographie par cohérence optique spectral domain (Cirrus SD-OCT), et la sensibilité rétinienne estimée en périmétrie automatisée. Comparer l'aptitude diagnostique des mesures de la couche des fibres optiques (RNFL), de la tête du nerf optique $(\mathrm{ONH})$ et du complexe ganglionnaire maculaire (MGCC) en OCT Cirrus.

Matériel et méthodes : 142 sujets (55 glaucomateux, 47 suspects et 40 cas témoins) ont bénéficiés de façon prospective d'une mesure de l'épaisseur RNFL, de la topographie de la tête du nerf optique (ONH et NRR) et de l'épaisseur MGCC par Cirrus OCT, et d'un relevé du champ visuel par périmétrie automatisée Humphrey 24.2 SITA Standard. L'épaisseur de la couche des fibres optiques (RNFL) de 12 secteurs péripapillaires de $30^{\circ}$, l'épaisseur de l'anneau neuro-rétinien (NRR) fournie par l'OCT Cirrus et la distance minimale entre la terminaison de la membrane de Bruch et la limitante interne (BMO-MRW), mesurées à partir de 36 scans espacés de $10^{\circ}$ de l'anneau neuro-rétinien, ont été collectées. Les relations entre les paramètres structuraux et la sensibilité rétinienne ont été évaluées globalement et pour 6 secteurs circum-papillaires (classification de Garway-Heath: inféro-nasal, inféro-temporal, temporal, supéro-temporal, supéro-nasal et nasal) par régression logarithmique. Pour l'ensemble des paramètres d'analyse (RNFL, ONH, MGCC), les courbes ROC (Receiver Operating Characteristics) ont permis de comparer l'aptitude à différencier les yeux glaucomateux ou suspects des yeux sains.

Résultats : L'association $\left(r^{2}\right)$ entre la sensibilité rétinienne et les épaisseurs RNFL, de l'anneau neurorétinien mesurés par l'OCT Cirrus (NRR) et la distance minimale entre la membrane de Bruch et la limitante interne (BMO-MRW) variait respectivement de 0,07 à 0,60 , de 0,15 à 0,49 et de 0,24 à 0,66 . La relation structure-fonction était plus forte pour la distance BMO-MRW que pour l'épaisseur NRR mesurée par l'OCT Cirrus.

L'aire sous la courbe ROC la plus large correspondait à l'aire de l'anneau neurorétinien (NRR) $(0,926-I C 95 \% 0,875,0,977)$ pour les yeux glaucomateux, et à l'épaisseur RNFL moyenne $(0,863$ - IC95\% 0,769, 0,957) pour les yeux suspects.

Discussion : La relation topographique est plus forte avec la distance BMO-MRW qu'avec les mesures RNFL ou de l'anneau neurorétinien mesurées par l'OCT Cirrus. La sensibilité rétinienne est mieux corrélée avec la mesure RNFL dans les glaucomes débutants alors que la corrélation semble plus forte avec la mesure de l'anneau neurorétinien dans les glaucomes avancés.

Conclusions: La relation structure-fonction était significativement plus forte avec le nouveau paramètre BMO-MRW qu'avec l'épaisseur de la couche des fibres optiques (RNFL) ou l'épaisseur de l'anneau neuro-rétinien (NRR) fournies par l'OCT Cirrus. Les meilleurs paramètres pour distinguer les patients glaucomateux et suspects des yeux sains étaient l'aire de l'anneau neurorétinien (NRR) et l'épaisseur RNFL moyenne.

MOTS CLÉS : glaucome, champ visuel, relation structure-fonction, tomographie par cohérence optique. 